\title{
Sustainability in Refugee Camps: A Systematic Review and Meta-Analysis
}

\author{
Mai Wardeh *(D) and Rui Cunha Marques \\ Civil Engineering Research and Innovation for Sustainability (CERIS), Instituto Superior Técnico, \\ University of Lisbon, 1049-001 Lisbon, Portugal; rui.marques@tecnico.ulisboa.pt \\ * Correspondence: mai.wardeh88@gmail.com
}

check for updates

Citation: Wardeh, M.; Marques, R.C. Sustainability in Refugee Camps: A Systematic Review and Meta-Analysis. Sustainability 2021, 13, 7686. https://doi.org/10.3390/ su13147686

Academic Editor: Anna Mazzi

Received: 23 May 2021

Accepted: 3 July 2021

Published: 9 July 2021

Publisher's Note: MDPI stays neutral with regard to jurisdictional claims in published maps and institutional affiliations.

Copyright: (c) 2021 by the authors. Licensee MDPI, Basel, Switzerland. This article is an open access article distributed under the terms and conditions of the Creative Commons Attribution (CC BY) license (https:// creativecommons.org/licenses/by/ $4.0 /)$.

\begin{abstract}
Many studies have stated the results of interventions presented in refugee camps to improve the quality of refugees' lives and reduce their suffering. However, there has been no formal systematic review and meta-analysis comparing the evidence of the relative effectiveness of these interventions along with sustainability and the current 2030 Agenda. We developed a comprehensive search strategy designed to identify all peer-reviewed articles that presented interventions related to Sustainable Development Goals (SDGs) in a refugee camp setting. We examined only articles with a specific focus on development goals. We screened the titles and, where necessary, the abstracts of 1108 publications. Seventy-two studies were judged to contain relevant evidence and were reviewed in detail. Data were extracted from these studies and pooled by meta-analysis to provide summary estimates of the effectiveness of existing procedures. Health and education sectors were the most frequently discussed SDGs. Results and recommendations from included studies were categorized into seven sectors: planning, development, and shelters; health and well-being; education; water and sanitation; energy; work and economic growth; and others. In order to improve the quality of life of refugees and internally displaced persons living in camps, more research that addresses both SDGs and camp planning and management is needed. This study is the first review found in the literature to report on sustainability in refugee camps.
\end{abstract}

Keywords: refugee camp; Sustainable Development Goals (SDGs); Millennium Development Goals (MDGs); review

\section{Introduction}

The number of people affected by conflicts is growing worldwide. As of mid-2020, the United Nations High Commissioner for Refugees (UNHCR) documented 26.3 million refugees. Yet controversy about refugee camps (RCs) and their longevity persist, which is a problem magnified by time. However, RCs, mainly those affected by the political crisis, are still considered as a temporary issue, even when there is evidence that these crises will stay for a long period.

While the Sustainable Development Goals (SDGs) were agreed on by world leaders in 2015 as part of the UN 2030 Agenda for Sustainable Development, 12 SDGs out of 17 are relevant to persons of concern to UNHCR, including refugees and internally displaced persons (IDP) [1]. A new document by UNHCR sets out the ways in which the SDGs and the Global Compact on Refugees (GCR) are aligned, where the document proposed a complementary framework to ensure that refugees and their host communities (HCs) are not left behind through development procedures. It highlights the contribution made by the GCR related to 16 SDGs [2]. An outstanding question that comes to mind is to what extent RCs are sustainable and whether sustainability, SDGs, and their targets are taken into account when it comes to a RC.

This study focuses on both Millennium Development Goals (MDGs) and SDGs of the largest up-to-date set of peer-reviewed papers focusing on RCs. This review seeks to answer the following questions: What are the existing studies highlighting strategies, 
projects, and plans that considered one or more of development goals and targets in RC settings? What do we know about the success and challenges of the given procedures? What are the implications for practice and what works well in RC to "leave no one behind"?

This literature review consists of four sections. Following this brief introduction, Section 2 displays the proposed methodology, including some definitions, search strategy and eligibility, and data extraction and synthesis. Then, Section 3 discusses the results of our research concerning the publications categorized according to the SDGs for the following sectors: (1) planning, development, and shelters; (2) health and well-being; (3) education; (4) water and sanitation; (5) energy; (6) work and economic growth; and (7) others. Finally, Section 4 draws the concluding remarks.

\section{Methods}

A literature review is adopted as a systematic review and meta-analysis research methodology in order to identify existing relevant peer-reviewed studies of issues related to the SDGs in RCs and to evaluate their respective contributions.

\subsection{Definitions}

According to the 1951 Convention, a refugee is "someone who is unable or unwilling to return to their country of origin owing to a well-founded fear of being persecuted for reasons of race, religion, nationality, membership of a particular social group, or political opinion" [3]. In this review, refugees is a word used both for people displaced outside their country of origin and for asylum-seekers who have not yet been given a refugee status, while IDPs are those displaced within their country of origin.

Although refugee accommodation has different types and an RC is defined as "a plot of land temporarily made available to host refugees fleeing from armed conflict in temporary homes" [4], in this review RC takes into account all types, including planned/managed camp, self-settled camp, a collective center, and a reception/transit camp. Moreover, sustainability accounts for both the 17 SDGs and the 8 MDGs.

\subsection{Search Strategy and Eligibility}

The eligibility criteria were defined to minimize the risk of selection bias [5], where exclusion criteria include published duplications and papers not published in peer-reviewed journals. Inclusion criteria comprise articles that contain the required information relevant to the research question.

The target electronic databases are Scopus (scopus.com) and Springer (springerlink.com) and Google Scholar (scholar.google.com). There are 1108 studies that mentioned either "refugee camp" and "Sustainable Development goals" or "Millennium Development Goals". The databases were searched in all fields using the terms: ("refugee camp" AND "SDG" OR "Sustainable Development Goal" OR "MDG" OR “Millennium Development Goal”). Keywords were chosen precisely to only capture those papers that are specifically relevant. Having comprehensive keywords such as "sustainability" or "development" or "refugees settlement" in general may lessen the probability of missing relevant papers. However, time limitations and our focus on planned camps and SDGs and MDGs, in particular, make more sense to be more precise about the keywords mentioned above. This review consisted of four steps: (1) selection and evaluation of studies, (2) classification, (3) analysis of the content of selected articles, and (4) the description of the results. The research has a number of classifications according to the main area of the subjects of the papers.

Publications were excluded based on the criteria outlined in Table 1 . The titles and abstracts of publications were screened and initially 101 papers were found after removing the duplicate publications identified from different databases. Full text of the sources reviewed and 72 sources were included for this literature review. 
Table 1. Exclusion criteria for a systematic review of sustainability in the refugee camps.

\begin{tabular}{ll}
\hline Exclusion Criteria & \multicolumn{1}{c}{ Subcriteria } \\
\hline Wrong study type & $\begin{array}{l}\text { Not a peer-reviewed article; book chapter; documents that do not } \\
\text { provide any conclusion or recommendation related to refugees in camp } \\
\text { Neither SDGs nor MDGs mentioned }\end{array}$ \\
Not related to SDGS & $\begin{array}{l}\text { Urban refugees, refugee's community, migrant, any other sitting not } \\
\text { related to camps }\end{array}$ \\
Wrong setting & -
\end{tabular}

\subsection{Data Extraction and Synthesis}

The following data were extracted from included publications: metadata (e.g., paper title, author, year of study ... ); contextual characteristics (e.g., study country/countries); population characteristics (e.g., the origin of refugee/asylum seeker/IDP population); type of development goals (SDGs, MDGs, both); number of related goals (e.g., SDG1, MDG1, etc.).

\section{Results and Discussion}

\subsection{Search Results and Publication Characteristics}

The search yielded 1108 sources (Figure 1). Table A1 in Appendix A presents the metadata of the 72 publications included; $72.2 \%(n=52)$ of the publications included mentioned SDGs at least once, $23.6 \%(n=17)$ mentioned MDGs, while 2.8\% $(n=2)$ mentioned both SDGs and MDGs, and only one publication mentioned post-2015 MDG (Figure 2).

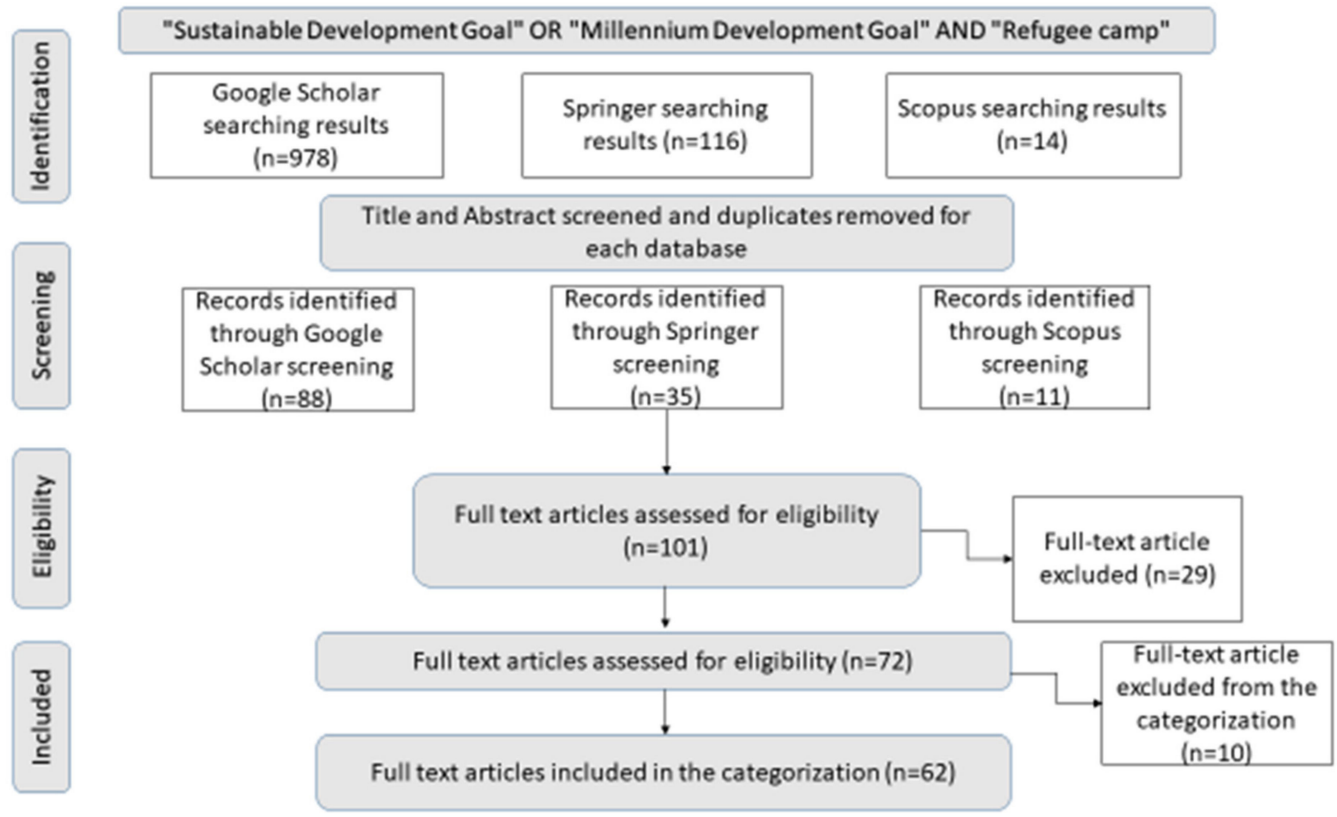

Figure 1. Preferred reporting items for systematic reviews and meta-analyses (PRISMA) flow diagram of a systematic review on sustainability in refugee camps. 


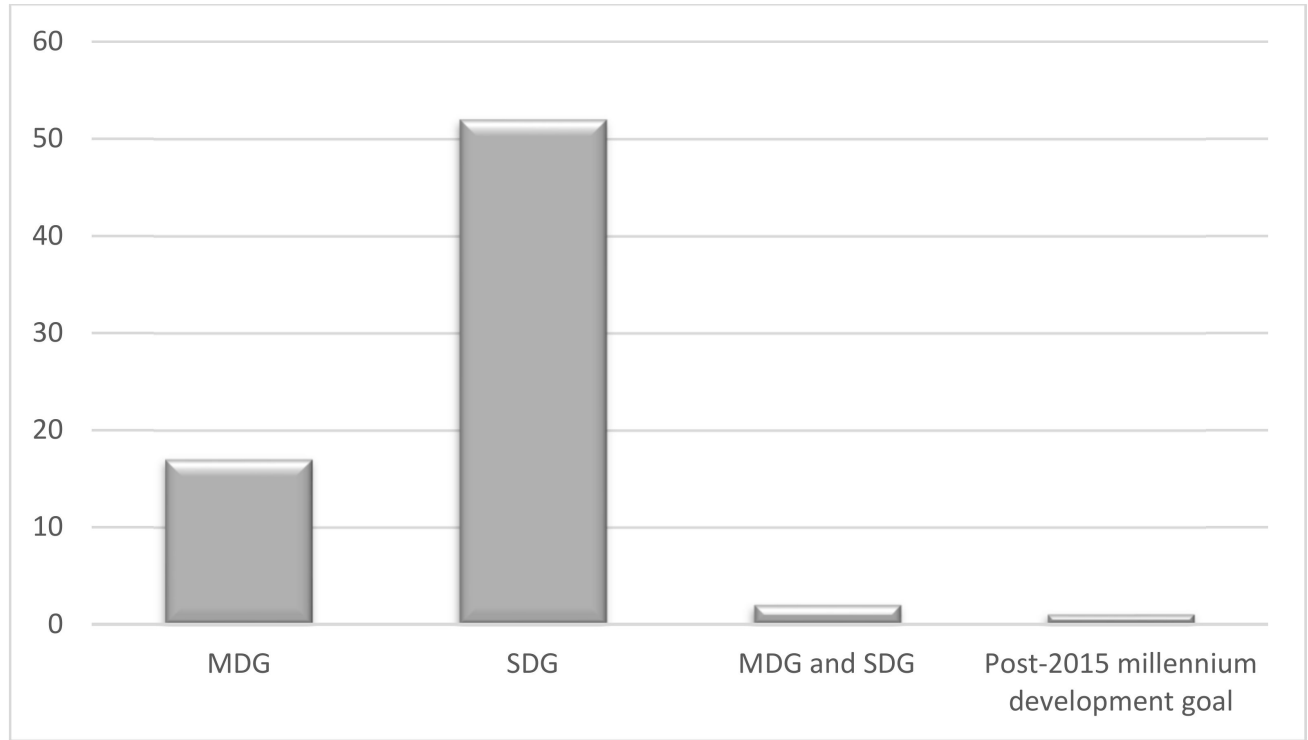

Figure 2. The way development goals were mentioned in the publications.

Publications about sustainability on RCs or related topics were not found prior to 2010 (Figure 3) and this may be due to the fact that the MDGs were launched in 2000. Moreover, the subject of sustainability and SDGs are new subjects that are receiving more attention lately. Furthermore, such research may have been a low priority prior to 2011, and the Syrian refugee influx received significant media attention, in addition to the fact that the number of refugees and displaced persons (DP) have increased significantly in the past ten years. As a result, researchers have been more aware of the RC context. Only 20.8\% $(n=15)$ of the publications that mentioned development goals on RCs were published between 2010 and 2015. More than half of the publications, 58.3\% $(n=42)$, were published after 2018, while almost a third of publications, 29.2\% $(n=21)$, took place in 2020.

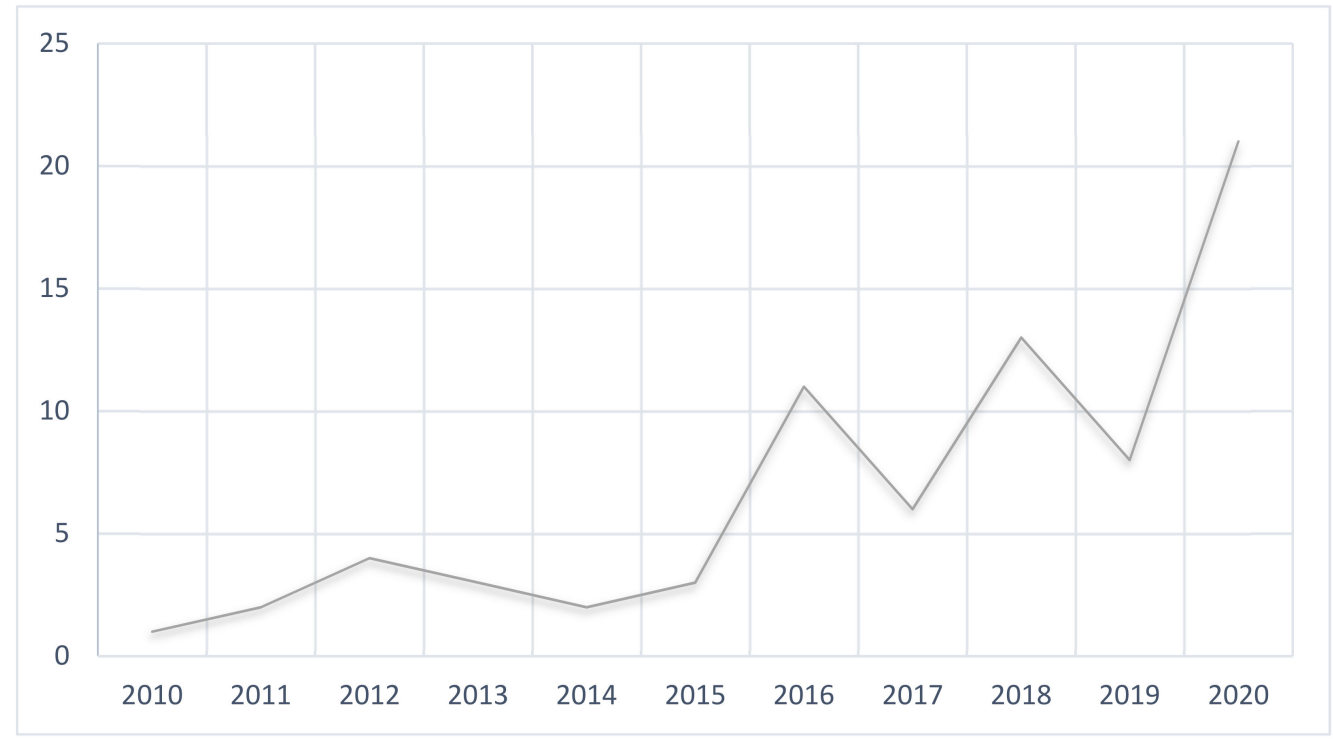

Figure 3. Number of publications, years 2010-2020.

Among 72 papers, only one was published in other languages (German) [6]. The papers were published in 58 journals by 291 authors, one of them is a group called "Global Emergency Medicine Literature Review Group" [7]. The top first authors publishing papers were Rose McGready and François Nosten. Both are from Shoklo Malaria Research Unit, Mahidol-Oxford Tropical Medicine Research Unit, Mahidol University and Centre 
for Tropical Medicine and Global Health, University of Oxford, with 10 articles. They published about $16.7 \%(n=12$ papers) related to SDG3 and MDG5, mainly regarding maternal and child health on the Thailand-Myanmar border. The top second and third authors publishing papers were their team with four and three publications for four authors each. While $7.2 \%(n=21)$ of the authors published two papers, the majority of the authors, $89 \%(n=259)$, published only one paper. Fifteen articles were single-authored, and onethird of the articles were written by no less than six authors. The highest number of authors was with the article of McGready et al. [8] with 23 authors, followed by Thielemans et al. [9] and Salisbury et al. [10] with 15 and 13 authors, respectively.

Fourteen papers (19.4\%) were published in four journals (Table 2). The journals with the highest number of papers are PLoS One and Conflict and Health with four papers, followed by Reproductive Health, and BMC Pregnancy and Childbirth with three papers each. There is a wide variety of journals because the topic is quite diverse and belongs to several areas. The most cited paper is Bellos et al. [11] with 98 citations, followed by Urdal and Che [12] with 87 citations. Table 3 presents the top 10 cited articles.

Table 2. Top journals according to the number of published articles.

\begin{tabular}{lc}
\hline The Name of the Journal & Number of Included Publications \\
\hline PLoS One & 4 \\
Conflict and Health & 4 \\
Reproductive Health & 3 \\
BMC Pregnancy and Childbirth & 3 \\
Journal of Palestinian Refugee Studies & 2 \\
International Journal for Equity in Health & 2 \\
Journal of Humanitarian Logistics and Supply Chain & 2 \\
Management & \\
\hline
\end{tabular}

Table 3. Top 10 cited articles.

\begin{tabular}{|c|c|c|c|c|c|}
\hline \multirow{2}{*}{ Article } & \multirow{2}{*}{ Year } & \multicolumn{2}{|c|}{ Total Number of Citations } & \multicolumn{2}{|c|}{ Average Citation Per Year } \\
\hline & & No. & Rank & No. & Rank \\
\hline $\begin{array}{l}\text { The burden of acute respiratory infections in } \\
\text { crisis-affected populations: A systematic review }\end{array}$ & 2010 & 98 & 1 & 9.8 & 3 \\
\hline $\begin{array}{l}\text { War and gender inequalities in health: The impact of } \\
\text { armed conflict on fertility and maternal mortality } \\
\text { Effect of early detection and treatment on malaria }\end{array}$ & 2013 & 87 & 2 & 12.4 & 1 \\
\hline $\begin{array}{l}\text { related maternal mortality on the north-western border } \\
\text { of Thailand 1986-2010 }\end{array}$ & 2012 & 72 & 3 & 9 & 4 \\
\hline $\begin{array}{l}\text { A study of refugee maternal mortality in } 10 \text { countries, } \\
2008-2010\end{array}$ & 2012 & 51 & 4 & 6.4 & 6 \\
\hline Energy services for refugees and displaced people & 2016 & 40 & 5 & 10 & 2 \\
\hline $\begin{array}{l}\text { High rates of pneumonia in children under two years of } \\
\text { age in a south east Asian refugee population }\end{array}$ & 2013 & 38 & 6 & 5.4 & 9 \\
\hline $\begin{array}{l}\text { Evaluating a vocational training programme for women } \\
\text { refugees at the Zaatari camp in Jordan: women } \\
\text { empowerment: A journey and not an output }\end{array}$ & 2016 & 32 & 7 & 8 & 5 \\
\hline $\begin{array}{l}\text { Neonatal intensive care in a Karen refugee camp: } \\
\text { A 4-year descriptive study }\end{array}$ & 2013 & 29 & 8 & 4.1 & 10 \\
\hline Urban crises and the new urban agenda & 2016 & 24 & 9 & 6 & 8 \\
\hline $\begin{array}{l}\text { Challenges and opportunities of new energy schemes } \\
\text { for food security in humanitarian contexts: } \\
\text { A selective review }\end{array}$ & 2017 & 19 & 10 & 6.3 & 7 \\
\hline
\end{tabular}

Included publications studied RCs in 29 different locations. Thailand (ThailandMyanmar border) is the most studied host country with $16.7 \%(n=12)$ of the publications; $77.8 \%(n=59)$ of the publications specify the countries in which the studied camp is located, $15.3 \%(n=11)$ made the study in more than two countries; $22.2 \%(n=13)$ are general studies in which the country was not determined-almost half of those studies $46.1 \%(n=6)$ are review studies and one is an opinion editorial paper [13]. 
Figure 4 shows the continents of the HCs' locations that were mentioned in the papers. Africa is the most mentioned continent with 14 different countries, followed by Asia with 11 different countries. North America was mentioned once as a host country for refugees who lived in camps before and not as a country that hosts an RC [14]. The study that has the highest number of host country locations is the study of Hynes et al. [15], where they studied refugee maternal mortality in 25 camps in 10 countries.

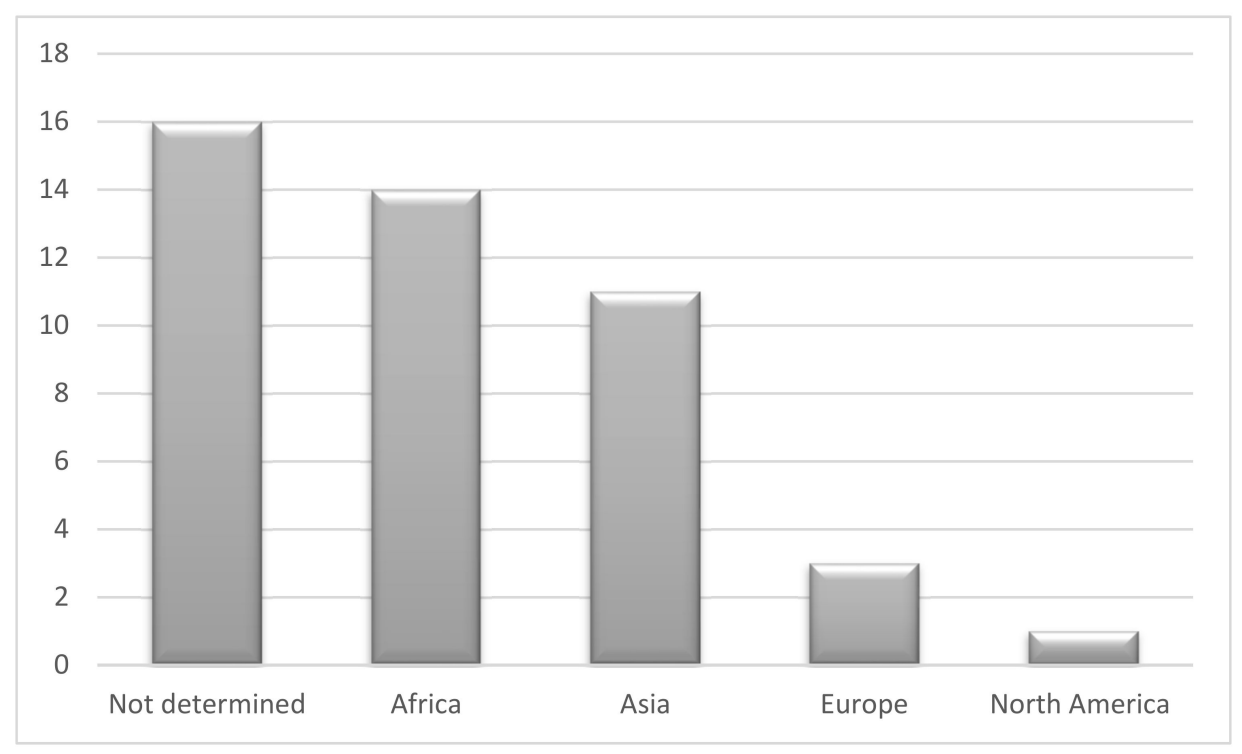

Figure 4. Continents of host countries in the included publications.

The most-reported refugee community is from Myanmar with $22.2 \%(n=16)$ of the publications, followed by Sudan and South Sudan with $208 \%(n=15)$. Note that the majority of refugees and their host countries come from low and low-medium economy countries.

The health sector, including SDG3, MDG4, MDG5, and MDG6, is the most represented sector in the included literature with more than one-third of the publications, 36.1\% $(n=26)$ (Table 4). The second mentioned sector is education, including SDG4 and MDG2, with $20.8 \%(n=15)$. SDG9 is mentioned once but it is not the focal point in the paper of Ajibade and Tota-Maharaj [16], and SDG 12, 14, and 15 are not mentioned in the publication. It could be because those SDGs are considered as less important in humanitarian contexts.

Table 4. Number of publications according to the number of focal development goals in the paper.

\begin{tabular}{lll}
\hline \multicolumn{1}{c}{ Development Goals } & $\begin{array}{c}\text { Count of Publications with a } \\
\text { Study-Specified Development Goal }\end{array}$ \\
\hline MDG1 & Eradicate extreme poverty and hunger & 3 \\
MDG2 & Achieve universal primary education & 1 \\
MDG3 & Promote gender equality and empower women & 1 \\
MDG4 & Reduce child mortality & 5 \\
MDG5 & Improve maternal health & 7 \\
MDG6 & Combat HIV / AIDS, malaria, and other diseases & 1 \\
MDG7 & Ensure environmental sustainability & 2 \\
SDG1 & No poverty & 1 \\
SDG2 & Zero hunger & 1 \\
SDG3 & Health and well-being & 14 \\
SDG4 & Quality education and promote lifelong learning & 14 \\
SDG5 & Gender equality & 5 \\
SDG6 & Water and sanitation & 3 \\
SDG7 & Affordable, reliable, sustainable and modern energy & 5 \\
SDG8 & Sustained, inclusive, and sustainable economic growth & 2 \\
SDG9 & Industry, innovation, and infrastructure & 1 \\
SDG10 & Reduced inequalities & 1 \\
SDG11 & Sustainable cities and communities & 3 \\
SDG13 & Climate action & 1 \\
SDG16 & Peace, justice, and strong institutions & 6 \\
SDG17 & Partnerships for the goals & 1 \\
\hline
\end{tabular}




\subsection{Publication Categorization}

This section presents the studies that specify at least one development goal in particular. We found 62 studies that mention one MDG or SDG in particular, while 10 studies are excluded at this stage since they have not determined a specific goal or target of any SDG or MDG; instead, they only mention SDGs or MDGs in general.

\subsubsection{Planning, Development and Shelters}

While SDG11 aims to "make cities and human settlements inclusive, safe, resilient and sustainable" [2], only four studies highlight the issue of planning and shelters, including SDG11 and MDG7.

The first study [17] argues that the global policy framework for crisis response needs to be changed to be efficient and to better understand how DP should be involved within complex urban settings. Repairing current systems of cities to meet the needs of DP is needed to assure that emergency interventions contribute to long-term urban development goals. RC is expensive and creates stigma and dependency on aids. It can be a place of violence and exploitation. Where transitional shelters are planned to last for a few years, the shelters turn to slums, having long-lasting negative consequences on the urban fabric, and do not fit the sustainable urban planning of the city. The exclusion of development prospects in humanitarian response can prevent long-term recovery.

The second study [18] compared the traditional approach to design RC with the new approach depending on three dimensions (time, space, and sources). The tradeoff between a permanent and temporary solution must be identified during the planning phase. Although there is a transformation toward the new approach, most camps are established utilizing the traditional top-down, temporary, and isolated approach. The study concludes that camp design guidelines need to be developed to fit the needs of refugees, HCs, and the development process, but having a universal design approach is impossible because selection depends on a number of factors. If RCs are considered long-term settlements, then urban planners and architects should be a vital part of the process to provide an efficient and sustainable design. The study affirmed that refugees can bring economic growth and benefits instead of being seen as a drain on resources.

The third study [19] discusses the political, social, and economic circumstances in which fire risk is experienced. It studies how the lack of planning and poor materials; type of energy used for cooking, heating, and other related needs; and lack of accessibility and communication can lead to more fires and crises in RCs. However, urban fire is still quite invisible in disaster management policy and practice because of the lack of data on fire incidence and causal factors.

The fourth study [20] examines the commercial area (souk) in an informal settlement which was a Palestinian RC in Beirut. The study mentioned MDG7 with its indicator being "secured from eviction" as an attempt to decrease the spread of informal settlements. The study shows how the lack of quality planning and policies lead to disastrous consequences and concluded that RCs should be removed worldwide and alternatively, refugees should be merged into their HCs. Furthermore, it encouraged the host government to facilitate and provide basic human needs such as education, job opportunities, and health services for informal residents for better well-being behavior. The study linked MDG7, which can be considered SDG11 in the 2030 Agenda, to SDGs (3-8) and SDG16.

These studies, related to SDG11, discussed indirectly how SDG11 is connected to SDGs (1-10), SDG13, SDG16, and SDG17. The four studies [17-20] concluded that the socialpolitical-economic aspects for each settlement are complex, and both Jahre et al. [18] and Rush et al. [19] confirmed that one solution does not fit all. However, all studies under this category conclude that political aspects are the most effective factor in this situation. In addition, collaboration between human organizations, local authorities, and government and development actors is needed, along with the integration of both refugees and HCs to improve the planning of RCs to achieve better and sustainable urban areas. 


\subsubsection{Health and Well-Being}

SDG3 aims to "ensure healthy lives and promote well-being for all at all ages" [2]. Almost one-third of the studies $(n=26)$ were sorted under these categories, comprising studies that mentioned SDG3 and either MDG3, MDG4, or MDG6. Forty percent of the existing studies $(n=10)$ were made in the Shoklo Malaria Research Unit (SMRU) on the Thai-Myanmar border that has a long and complicated history of conflict and human displacement. Shoklo Malaria Research Unit has provided humanitarian health care for refugees since 1986 and for migrants since 1997 [8,10,21-28].

Table A2 in Appendix B shows studies under this category. The studies linked SDG3 directly or indirectly to all SDGs, except for SDG12 and SDG14. However, SDG3 was mostly affected by education SDG4, where people who are educated were more aware of threats, instructions, and their health care rights. Figure 5 shows the percentage of studies according to goals and targets of SDG3. Target 3.1 relates to maternal mortality and was the one most studied, with $32.77 \%$, followed by target 3.7 , which aims to ensure global access to sexual and reproductive health care services, including family planning, information, and education, and the integration of reproductive health into national strategies by 2030 [29], with $26.92 \%$.

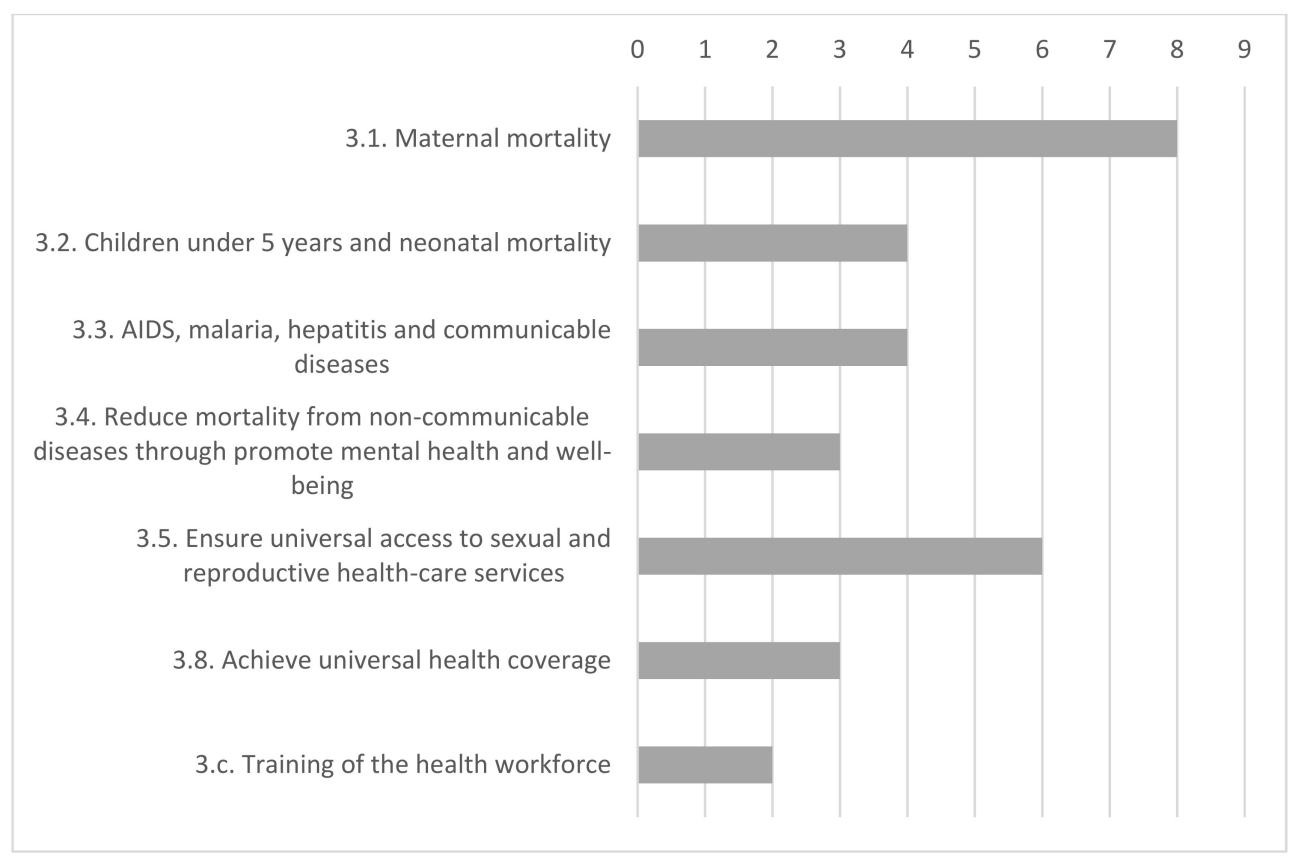

Figure 5. Number of studies according to goals and targets of SDG3.

Language is one of the most mentioned barriers, together with cultural context, lack of data, legal, political environment, and related policies of the host country, such as lack of support of sexual and reproductive healthcare services. Having volunteers from refugees themselves built a trusting relationship between them and the vulnerable women, improved self-confidence, reduced feelings of loneliness, and overcome barriers to healthcare fulfilment. Intervention related to refugee should take the value of cultural competency and the individual into account. Support is needed at all levels (local, national, and international). Measurable indicators that are related to SDGs, including family planning, antenatal care, HIV / AIDS screening, and sexually transmitted infection care, should be improved in RCs to achieve the minimum initial service and help achieve SDG3 and other related SDGs.

\subsubsection{Education}

Quality education is the fourth goal of the 2030 Agenda. SDG4 targets to ensure inclusive and equitable quality education and promote lifelong learning for all [30]. More 
than half of the refugee children worldwide (3.7 million) are out of school and this number increases by half a million each year. Only $63 \%$ of refugee students attend primary school compared to $91 \%$ worldwide, while $24 \%$ are able to attend secondary school compared to $84 \%$ globally. However, higher education stays at the worst place with only $3 \%$ of refugees attending any form of higher education compared to 37\% globally [31].

Sixteen studies were included in this review. Three studies (18.75\%) addressed education in general, including all stages: preschool, primary, secondary, and tertiary education [32-34]. Two studies $(12.5 \%)$ [35,36] discussed early childhood education. Seven studies $(43.75 \%)$ addressed only schools [37-43], while two of these $(28.6 \%)[39,41]$ addressed the stage of primary school. Two studies (12.5\%) addressed higher education [44,45] and both addressed the use of technology to provide higher education in RCs context, while two studies $(12.5 \%)[46,47]$ addressed vocational training.

The study of Irfan [37] argues that despite the practical problems to accessing education, other aspects, including insecurity, danger, and psychological trauma, should be taken into account. It concludes that to connect SDG4 to reality, a comprehensive approach that considers education as a significant service is needed, in addition to emergency relief, highlighting the importance of inclusive and quality education, lifelong learning, gender equity, and human rights.

Osman and Bin Ahmad Dahlan [46] propose a business model to help Eritrean refugees in Sudan with a focus on quality education and SDGs targets. The paper displays a comprehensive value proposition canvas that fits the refugees' needs and recommends increasing efforts from all organizations, donors, and countries. RCs face many challenges, including lack of schools, teachers, and educational resources, in addition to poverty and hunger. The paper suggests building comprehensive business models with educational, technological, and financial programmes to help refugees gain essential educational skills that empower them to overcome their problems and to contribute to the development of their community through gaining jobs and creating new job opportunities. Hence, note the interconnection between SDG4 and SDG8.

Jabbar and Zaza [47] assess a vocational training programme for women refugees and shows how it helps reach MDG3 by empowering women and generating intrapreneurship and work opportunity, In addition, it affects positively the mental health of women and raises self-confidence. The study connected this kind of programme under SDG4 to help achieve SDG3, SDG8, SDG5, SDG10, and SDG16 in the RC context.

Laxton et al. [35] show a case study of a project that merges both technology and volunteering to meet the needs of different communities and enhances early childhood education in the Rohingya RCs of Bangladesh. The project aims to meet the challenge of SDG4 and SDG5 by offering opportunities for mothers/big sisters to overcome gender inequalities by leading educational practice transformation in the community. The paper suggests that tents could be a safe place for children to play and learn on a regular basis. It concludes that creating and maintaining good relationships is essential to enable efficient collaboration between stakeholders, which are represented by SDG17, and it serves both marginalized women and children.

Santo and Scott [36] show how shelters can be modified to be a safe space for refugees to lead and provide continuous support to their communities. It also shows an example of how a refugee-led program empowers marginalized women to play their roles as leaders and educators. Both studies $[35,36]$ show the connection between SDG4, SDG5, and SDG17. In addition, they highlight the importance of innovation in the most vulnerable environments connected to SDG9.

Two studies $[44,45]$ deal with the use of technological solutions to meet international goals, and how higher education content delivered via innovative methods that aim to build connection between university-level topical knowledge, digital literacy, and other skills help in the future reconstruction in postconflict communities. Higher education is a key to the rebuilding in the postconflict phase. 
Although the study of Schön et al. [33] focuses on self-reliance in the camp environment, it confirms the importance of education to help refugees be self-reliant, and connects SDG4 with SDG8. Moreover, it mentioned that in a city-like camp, which has not yet existed, refugees should have all benefits that urban camps offer, along with better education systems.

Two studies [34,39] connect education to the well-being of refugees. The study of Obodoruku [34] in Turkey indicates that the basic information and education are required to enhance the refugees' well-being in camps. It shows that refugees lack equal access to education and information and lack of access to the UNHCR to report hostile treatment. The study highlights the importance of policy applied by the host government and suggests that host governments should understand the challenges that refugees face to obtain sustainable development by providing the required educational equipment for refugees, and includes the refugees' expertise and laborers that can produce new employment opportunities and end poverty.

Two studies [38,42] expose the connections between reaching SDG4 through SDG16. Meyer et al. [38] show the links between violence and educational results among adolescent refugees in humanitarian settings (camps and settlements). The results indicate that the educational environment may not be consistently protective, and educational outcomes may be improved by prevention of violence at schools. Plessia [42] discusses that integration of unaccompanied minors in the Greek educational system poses challenges due to the language barrier and a denial to participate. Furthermore, the identification of children requires a long time. It also highlights that managing and supporting unaccompanied minors is a proof of European solidarity and not only a legal-based responsibility. Hence, SDG17 can be referred here.

Katsigianni and Kaila [39] present a case study of a primary school in Greece where refugee students were transported to local school units with buses paid for by an international organization. This integrated the refugee students into the educational system as a way to help children return to a normal daily life. The study shows how the first oppositional reaction by the $\mathrm{HC}$ affected the cooperation potential and the entire school environment, and how it later changed. Where the educational system was not well prepared to introduce refugees to both education and $\mathrm{HC}$, it seemed that social opposition sometimes limited the acceptance and solidarity within the host school community. In some cases, the lack of introductory programmes caused distrust and denial and more time is needed to handle the difficulties. Long-term programmes that empower the school unit and teachers, along with the cooperation between families, school, and the local community, have positive effects and drastically contribute to facing bullying and victimization incidents. Independent authorities and institutions that protect people's rights play an important role in promoting an argument that can oppose and undermine intolerant behaviors.

The study of Akua-Sakyiwah [40] is the only one that mentioned MDGs on primary education even not directly. It shows how social structures, policy regulation, and implementation, aligned with refugees' personal experiences and responses to the circumstances, influence the refugee's settlement and affect the education of their children. It highlights that health issues due to traumatic experiences affect children's education, while there is no control from agents involved in the education and well-being of the child (teachers, the camp management, community leaders, parents, and health personnel). Unemployment problems lead to poverty, which affects the educational achievement of children, where adolescent girls and children work to help their families and causing them to miss classes. In addition, hunger and malnourishment affect children's performance, attendance, and their education. It also mentioned the issue of exclusion of refugee teachers and welleducated people out of the educational system because they are not allowed to work in the host country. Thus, how SDG1, SDG2, SDG3, and SDG8 affect the achievement of SDG4 can be concluded. 


\subsubsection{Water and Sanitation}

This category represents SDG6 which aims to "ensure availability and sustainable management of water and sanitation for all" [29]. Four studies were found that related to SDG6 and RCs.

The first study [48] is the only study that was made in a developed country (Germany) and it considers accommodation for DP that are single buildings distributed within existing cities. The study addresses the institutional response to displacement in developed urban contexts by examining the legitimization of the inclusion of cultural practices in the preparation of water and sanitation for DP. It concludes that institutional response to global displacement was more reactive than proactive. The study contributes to SDG6 by addressing the research necessary for provision of water and sanitation services. However, it did not consider the opinion of the DP and highlighted that as a limitation. From our perspective, it failed to understand the cultural background of the people while addressing the issue from an unrealistic perspective.

The second study [16] shows that improving the quantity of water supply made available to the refugees alone cannot solve the problem of water-related disease outbreaks. Other possible solutions, like the removal of localized ponds of water, should be taken into account. The study mentions that strategic incorporation of a sustainable drainage system into the drainage systems of RCs for stormwater management in the East African region can help achieve SDGs in 2030 (specifically goals 3.d, 6.a, 6.b, 9.a, 11.b, 13.1, and 13.2). The study tests the performance of a sustainable drainage system (engineered wetlands and filter drains) for attenuating stormwater and decreasing the concentration of pollutants in stormwater through a laboratory-scale experiment. All sustainable drainage systems reduced a notable proportion of runoff and decreased most of the pollutants tested over the duration of the experiment. However, the filter drain systems achieved the highest attenuation performance. Plants in the wetlands positively affected the degradation of chemical oxygen demand and biochemical/biological oxygen demand in stormwater samples. However, filter drains are more effective in removing turbidity and total dissolved solids in water samples. High attenuation effectiveness of the sustainable drainage systems can be an efficient flood and erosion management strategy over RCs. Moreover, including these sustainable drainage systems into the drainage systems of RCs can ease the achievement of SDGs across RCs by preventing water-related diseases, and also helps reduce the degradation of the environment and the impact of climate change on the camps.

The third study [49] is a systematic review that evaluated the quality (Escherichia coli, thermotolerant coliforms, and total coliforms) of drinking water in nonhousehold settings. The review found that drinking water in nonhousehold settings is often noncompliant with health-based standards as defined by the World Health Organization.

The study of Fatoni and Stewart [50] is the only study that mentioned MDG related to sanitation and discusses issues related to sanitation in the case of emergency after the eruption of Mt. Merapi in Indonesia. The study confirmed sanitation as a critical need during the earliest phase of the emergency and highlighted the issue of inadequate information and data collection, and the inappropriate technology selection along with the lack of health-promoting behaviors. It raised the issue of privacy and security, such as the case of neglecting provision of facilities for particular vulnerable groups, such as women during menstruation, and highlighted the importance community participation in the decision-making processes. Many of these issues can be approached at a relatively low cost with locally developed initiatives, as locally built latrines that do not require time or international partners, and by promoting adequate standards of hygiene.

This category represents one of the most important requirements that affect other SDGs, particularly SDGs $3-5$. Having real data and developing an innovative and low-cost solution that is culturally appropriate can help refugees have a better quality of life. In addition, policies applied in the host country and partnership between different agencies represented in SDG17 are vital to achieving SDG6. 


\subsubsection{Energy}

SDG7 aims to "ensure access to affordable, reliable, sustainable and modern energy for all" [29].

Khoday and Gitonga [51] present the situation in many host countries and RCs in the Middle East. It affirmed that innovative sustainable energy partnerships, which underline SDG17, are important and play a key role in bringing the advantages of green growth and innovation to the most vulnerable communities in the world, in line with the 2030 Agenda and SDG7.

Lehne et al. [52] conclude that refugees are between the furthest left behind communities regarding SDG7. The study determined initial estimates for the overall scale of energy poverty between refugees in camps and urban areas, and suggested three scenarios for developing energy access. It indicated that simple and cost-effective solutions can improve the access and suggested that moving towards a recognition of energy as a key element of humanitarian relief efforts is needed. It suggested possible approaches, including that planning for energy provision should be a key consideration in humanitarian response; a systematic approach to collecting data on fuel use, energy practices, and costs is needed and new long-term funding and delivery models should be explored.

Thulstrup et al. [53] present an essential connection between energy and food security in the humanitarian context. Energy-related challenges that refugees face stand against sustainable energy access. They discussed that solid biomass is usually used when people have no other choice and it is harmful in many ways and unsustainable. In addition, it highlighted that the lack of secure, affordable, and sustainable energy for cooking, heating, lighting, and powering has implications on various linked sectors and suggested that standardization of humanitarian operating procedures, innovative technologies, and new mechanisms should be developed to address the energy needs. In addition, changing the current policy is required to achieve SDG7, where the current humanitarian system is incapable of solving the energy challenge if the current response measures are not developed.

Benka-Coker et al. [54] report the implementation of ethanol as a household cooking fuel in Ethiopia. The study explores the use of CleanCook ethanol stoves in RCs, and low-income households informed that users found that ethanol stove is clean, safe, fast, and effective, but more expensive in comparison to solid fuels and not proper for making some specific necessary traditional foods; therefore, people use various types of stoves. The case study shows that introducing a new cooking fuel is complex.

Miller and Ulfstjerne [55] explore why energy interventions often fail to obtain the expected outcomes using Rhino Camp as a case study. It presented many fundamental problems in current interventions. It showed that rather than looking for the reasons behind the ineffectiveness of these interventions, stakeholders lay responsibility on the users. The study suggests that local knowledge should be included to have a successful energy intervention and that energy use is not an issue of cultural or individual practice only, but also rely on coexistence between refugees and the HC, and that both communities should take steps to adjust to resource scarcity. It also highlighted that technological enhancement should consider such adaptations throughout the process of ensuring modern energy for all.

Pearl-Martinez [56] discuss SDG7 and its implication on women in developing countries where women do not have equal chances to benefit from emerging opportunities that can help vulnerable communities access energy. This study raises awareness of six global trends that can help achieve SDG7. These include decentralization of energy services, affordability, mobile payments, women's entrepreneurship, urbanization, and humanitarian settings. The study concludes that achieving an equitable transformation to a sustainable energy system requires effort to be directed towards achieving gender equality. Access to sustainable energy should become a key and official component of humanitarian aid. Sustainable technologies and clean fuels should be a priority in humanitarian settings. Cooperation between international policy frameworks, humanitarian organizations, and national governments should exist toward adopting the coordinated energy access goals 
and assuring that women's requirements are evaluated and precisely coordinated. Helping refugees work provides the means for them to pay for the cost of energy services. Both HCs and DPs are benefitted when sustainable energy services are delivered at an affordable cost, and this facilitates the integration within the community. This will also help save scarce natural sources from gathering fuelwood. Ideally, when refugees enter the camp, they should receive a proper cookstove and fuel, and a solar lantern, and education on any new technology.

All studies under this category mentioned that SDG7 affected health SDG3 and security and gender-based violence of refugees and IDPs linked to SDG5. The majority addressed how energy affects people's food security and this shows the link between SDG7, SDG2, and the livelihood possibilities of SDG8. Some studies show that SDG7 is a key element for achieving SDG1 and SDG2. Moreover, they linked it to SDG4, SDG6, SDG9, SDG11, SDG13, and SDG17.

Having access to clean energy should be a must in humanitarian settings, since it reduces environmental implications caused by using harmful energy. Furthermore, creating an innovative solution through technology and policy and partnership help achieve SDG7 and related SDGs. Once again, there is no universal approach to the provision of energy to refugees and DP. Any approach that could be implemented should take into account multiple social, cultural, political, and environmental factors.

\subsubsection{Work and Economic Growth}

This category represents SDG8's aim to "promote sustained, inclusive and sustainable economic growth, full and productive employment and decent work for all" [29]. Three studies were included in our review.

The first study [57] discusses the socioeconomic conditions among Palestinians in Lebanon. Refugees should have access to basic civil rights and social inclusion, to improve their living conditions. The study concludes that to achieve SDG 1 and 8, inequitable laws and practices must be excluded, especially the principle of reciprocity of treatment and work permit requirement, and it suggests that the host government should encourage refugees to access the formal labor force, including the low-skill and elementary professions, and confirmed the dialogue between both stakeholders to guarantee employment rights and social inclusion for refugees.

The study of Schön et al. [33] focused on self-reliance in the camp environment. It confirmed the importance of education to help refugees be self-reliant and connected SDG4 to SDG8.

The study of Muhammad [58] emphasized that sustainable development assistance is needed and that both emergency relief inputs and long-term livelihood assistance should be included in humanitarian assistance for both DP and HC. This study recommends producing more equitable development, through clearly defined women's roles, and incorporates them into policies, plans, and institutional changes at various levels, including donor agencies to efficiently plan the delivery of development assistance to be equitable, sustainable, and case sensitive. The study suggests applying effective policy to address the threat of illegal activities that may occur when DP consider illegal livelihood strategies that may be harmful to refugees, HCs, and their governments. It indirectly connected SDG8 with SDG1-5, SDG10, SDG13, and SDG17.

The study of Osman and Bin Ahmad Dahlan [46], which was mentioned previously in the education part, presents a new business model and shows how SDG8 is connected to SDG4.

\subsubsection{Others}

Under this category, we found four studies, three relevant to SDG16: "promote just, peaceful and inclusive societies", and one related to SDG17 "global partnership for sustainable development". 
The study of Hayes [59] discusses the data protection issue and the challenges that humanitarian organizations face while offering assistance to refugees, IDP, and migrants. More efforts are required to ensure data protection in humanitarian settings. The study linked SDG16 to SDG1, SDG2, SDG3, SDG9, and SDG17.

Both Brinham [60] and Cheesman [61] discuss the documentation issues associated with displacement, which is related to SDG16.9, aiming to "provide legal identity to all". They show the importance of identification documents for refugees and DP as they provided visibility that features part of the 2030 Agenda, and in ways to prevent statelessness. Moreover, it presents the connection between SDG16 and SDG2, SDG3, SDG4, SDG5, SDG8, SDG9, SDG10, and SDG17.

The study of Moreno-Serna et al. [62] is the only study that discussed SDG17. It concluded that new patterns of collaboration between people and organizations are required to achieve the 2030 Agenda. Moreover, to assist partnership to reach the transformational state, this study suggests two important factors: a facilitating party that assures the creation of shared value and partners that own both the ambition and a cohesive strategy to work together to achieve significant systemic transformation. The study connected SDG17 to SDG4, SDG6, SDG7, SDG8, SDG9, and SDG13.

\section{Conclusions}

Sustainability in RCs seems to be receiving more attention in academia and practice over the past decade. However, more attention is required where there is a lack of studies that address the issue of development goals in RCs due to the fact that MDGs and SDGs are to some extent a new topic, also because RCs are considered as short-term settlement that does not need long-term interventions. More focus is given to humanitarian action while development actions are not yet accepted. Following the transformative promise of the 2030 Agenda of "leaving no one behind" and according to the review above, the conclusion and recommendations according to each category follow:

\subsection{Planning, Development and Shelters}

1. There is lack of research and even awareness about planning RCs, in particular, what is aligned with targets 11.2, 11.6, 11.7, 11.a, and 11.c, including:

- Transportation and green and public spaces for all, and for the most fragile population within refugees, including women and children, older persons, and people with disabilities;

- Environmental impact of RCs, including air quality and municipal waste management;

- Linking RCs to surrounding rural, pre-urban, and urban areas is important to support positive economic and social relations between refugees and their HCs, and to create a better environment for refugees to be self-reliant;

- Using both technology and local knowledge to build sustainable shelters is needed in the RCs.

2. The political aspects and policies that host countries apply play the most effective role in the situation and the future of refugees. We can conclude that policies applied should be changed, where RCs should no longer be a solution for a refugee influx. $\mathrm{RCs}$, in most cases, turn into permanent slums and unsafe informal settlements, which do not align with SDG11, in particular targets 11.1 and 11.2.

3. When the RC is the only proposed solution, long-term vision and policies should be taken into account, and current standards and approaches to planning a RC should be restudied, where "one standard fits all" is no longer accepted. Moreover, a bottom-up approach should be applied by considering the culture, religion, and local knowledge of the area, and merging them into a policy-making environment and planning phase.

\subsection{Health and Well-Being}

1. Research found that health and well-being in RCs was the topic most studied among all other categories. It found studies addressing targets 3.1, 3.2, 3.3, 3.4, 3.7, 3.8, and 
3.c. However, the targets most studied were 3.1 and 3.7, which are related to maternal mortality and sexual and reproductive health-care.

2. No studies were found related to targets 3.5, 3.6, and 3.9. Nevertheless, narcotic drug abuse, deaths, and injuries from road traffic accidents (due to the low quality of road and lack of lights), and deaths and illnesses from water pollution can be found in the camp environment.

3. Policy applied by the host country and language barrier was the most reported obstacles that affect the access of refugees to health. Host governments and health care providers should apply policies that can be met with finance to ensure that the right method is adopted towards achieving SDG3.

4. Training refugees to become skilled health workers is shown to be successful and has good results in a camp environment where there is a lack of skilled health workers; in addition, it helps reduce the language barrier.

\subsection{Education}

1. The education section was the second reported among all categories, and studies found it covered all targets of SDG4. Studies in this review presented many case examples that were applied in camp setting; these studies can be the foundation to develop better educational interventions in RC.

2. Studies showed how education plays a key role of empowering refuges, especially women, and help reduce gender inequality and achieve SDG5, SDG8, and SDG16.

3. Promoting refugee-led programs, volunteering, innovation, and technology to meet the need of education in refugee communities help empower marginalized refugees, especially women, and achieve SDG4 and connected SDGs.

4. Policy applied by the host country plays a key role in empowering refugees to continue their education in general and higher education in particular, where it is considered the worst in RC when compared to other education stages. At the same time, higher education is crucial to help refugees be self-reliant to build their future and their countries in the postconflict phase.

5. Language barrier affects the education process, so having translators and facilitators from within the refugee community can help overcome this challenge and provide better-quality education for refugees through different partners and cooperation.

\subsection{Water and Sanitation}

1. Studies showed how education plays a key role of empowering refuges, especially women, and helps reduce gender inequality and achieve SDG5, SDG8, and SDG16.

2. More robust research and innovation solutions are needed under this category to achieve SDG6.

3. Water and sanitation is one of the most significant requirements that affect the quality of life of refugees and the achievement of other SDGs, most importantly SDG3, SDG4, and SDG5.

4. Innovative, low-cost, and culturally appropriate solutions can be applied to meet refugees' need to access to safe drinking water and sanitation, and hygiene, especially for women and girls, which aligned with target 6.1, 6.2, 6.3, and 6a.

5. Policies applied in the host country, cooperation, and partnership are vital to achieving SDG6.

6. Availability of updated data is fundamental to the success of any intervention related to water and sanitation, and SDG6 as a whole.

\subsection{Energy}

1. The included studies covered all targets of SDG7 and presented different interventions and partnerships that were done in different locations, including cooking fuel, clean cooking stoves, energy to generate electricity for lights, and other purposes. 
2. Humanitarian aid should consider access to sustainable energy an essential and official component. Access to energy is generally ignored in humanitarian settings. Nevertheless, this issue is becoming more recognized by international interventions and cooperation in the last few years.

3. Using clean and sustainable energy for humanitarian aid can help reduce the cost after a number of years. Moreover, it will help improve the quality of life of refugees, conserve the environment, and reduce gender inequalities.

4. Cook energy is essential to end hunger and achieve SDG2.

5. Partnership between international policy frameworks, humanitarian organizations, and host governments play a key role in achieving SDG7 in humanitarian settings.

6. Culture and local practice and knowledge should be taken into account when presenting a new technology or type of energy. However, promoting sustainable and modern energy within refugees and educating them on using them will help overcome the obstacles that may appear when introducing new energy practice.

7. Providing energy in RC generates enterprises, job opportunities, and help achieving SDG8.

\subsection{Work and Economic Growth}

1. There is lack of studies that address the issue of refugees' access to decent work in a RC in the host country. More efforts are required to address SDG8 and in particular target 8.8.

2. Policies applied by the host government play the most important role in improving the living conditions of refugees and achieving SDG8.

3. Refugees should have basic rights, including the right to work.

4. Inequitable laws and practices applied by the host government can backfire. Therefore, the host government should assist refugees to access formal employment in all levels and professions.

5. Refugees' work can help them improve their living conditions and transfer them from receiving aid to generating income, which can help improve the economic growth of their $\mathrm{HC}$ and generate more job opportunities.

\subsection{Others}

1. More research regarding SDG16 and its targets should be done, including using innovation and developing technology to help ensure data protection in humanitarian settings.

2. Policies applied by the host government play a key role in achieving SDG16 and, in particular, targets 16.9 and 16.b.

3. More research on governance in RCs in line with SDG16 and targets 16.6 and 16.7, in particular, is required. Governance seems to be forgotten in RCs and more efforts are needed to engage refugees in the decision-making process at all levels.

4. More research about partnership to achieve SDGs is required to better understand the framework of working together and encouraging international community, governments, different institutions, and NGOs at all levels to cooperate together to achieve the SDGs.

Last but not least, the findings of the literature analysis suggest that leading research areas are the ones related to health and well-being SDG3, followed by education SDG4. Most researchers did not focus on SDGs themselves, but many fall into related research; therefore, a more comprehensive, consistent, and in-depth study should be made in the future, whether taking into account one target or more than one SDGs to improve the quality of aid provided to refugees, and help them become equal while helping to achieve the 2030 Agenda.

While lack of data, language barriers, and policy applied by the host government were the most mentioned obstacles, innovation, technology, and partnership, in addition to the policies, once again, are the most mentioned and related solution to help achieve the 
SDGs. We suggest building on existing literature and initiatives to develop measures of progress on sustainable development that support capacity-building and development in both RC and HC, and at the same time save the environment and our planet.

Although this study has theoretical contributions, several limitations still exist. The number of articles included in some categories is limited and additional related research may exist. However, they did not mention SDGs or MDGs and therefore they were not included in our review. Consequently, the results displayed may not be very robust regarding all categories; however, since our focus is on SDGs and MDGs, we believe this review makes good contributions to the literature.

Author Contributions: Both authors had the original idea of reviewing the subject within the context presented above. M.W. carried out the data collection and wrote the first draft of the article. R.C.M. reviewed and edited the first draft. Both authors contributed to subsequent drafts, which gave the manuscript its final form. All authors have read and agreed to the published version of the manuscript.

Funding: This research received no external funding.

Data Availability Statement: Additional data can be provided by request through email to the corresponding author.

Acknowledgments: The first author thanks and recognizes the generous support of her Global Platform for Syrian Students scholarship.

Conflicts of Interest: The authors declare no conflict of interest.

\section{Appendix A}

Table A1. Metadata of the included publications.

\begin{tabular}{|c|c|c|c|c|}
\hline No & Author(s) [Citation No.] & Names of Author(s) & Year & Title of the Article \\
\hline 1 & Earle [17] & \multirow{2}{*}{$\begin{array}{c}\text { Lucy Earle } \\
\text { Marianne Jahre, Joakim Kembro, Anicet Adjahossou, and } \\
\text { Nezih Altay }\end{array}$} & 2016 & \multirow{3}{*}{$\begin{array}{c}\text { Urban crises and the new urban agenda } \\
\text { Approaches to the design of refugee camps: An empirical } \\
\text { study in Kenya, Ethiopia, Greece, and Turkey } \\
\text { Towards a creative sustainable promenade in informal } \\
\text { souk architecture case study: Mar Eli as camps, in Beirut, } \\
\text { Lebanon }\end{array}$} \\
\hline 2 & Jahre et al. [18] & & 2018 & \\
\hline 3 & Youssef and Mefleh [20] & Maged Youssef and Farah Mefleh & 2019 & \\
\hline 4 & Rush et al. [19] & $\begin{array}{l}\text { David Rush, Greg Bankoff, Sarah-Jane Cooper-Knock, } \\
\text { Lesley Gibson, Laura Hirst, Steve Jordan, Graham } \\
\text { Spinardi, John Twigg, and Richard Shaun Walls }\end{array}$ & 2020 & Fire risk reduction on the margins of an urbanizing world \\
\hline 5 & Howard et al. [63] & $\begin{array}{l}\text { Natasha Howard, Aniek Woodward, Yaya Souare, Sarah } \\
\text { Kollie, David Blankhart, Anna von Roenne, and Matthias } \\
\text { Borchert }\end{array}$ & 2011 & $\begin{array}{l}\text { Reproductive health for refugees by refugees in Guinea } \\
\text { III: maternal health }\end{array}$ \\
\hline 6 & McGready et al. [8] & $\begin{array}{l}\text { Rose McGready, Machteld Boel, Marcus J. Rijken, } \\
\text { Elizabeth A. Ashley, Thein Cho, Oh Moo, Moo Koh Paw, } \\
\text { Mupawjay Pimanpanarak, Lily Hkirijareon, Verena I. } \\
\text { Carrara, Khin Maung Lwin, Aung Pyae Phyo, Claudia } \\
\text { Turner, Cindy S. Chu, Michele van Vugt, Richard N. Price, } \\
\text { Christine Luxemburger, Feiko O. ter Kuile, Saw Oo Tan, } \\
\text { Stephane Proux, Pratap Singhasivanon, Nicholas J. White, } \\
\text { and François H. Nosten }\end{array}$ & 2012 & $\begin{array}{c}\text { Effect of early detection and treatment on malaria related } \\
\text { maternal mortality on the north-western border of } \\
\text { Thailand 1986-2010 }\end{array}$ \\
\hline 7 & Hynes et al. [15] & $\begin{array}{c}\text { Michelle Hynes, Ouahiba Sakani, Paul Spiegel, and } \\
\text { Nadine Cornier }\end{array}$ & 2012 & $\begin{array}{l}\text { A Study of refugee maternal mortality in } 10 \text { countries, } \\
\qquad 2008-2010\end{array}$ \\
\hline 8 & Garcia and Gostin [64] & Kelli K. Garcia and Lawrence O. Gostin & 2012 & $\begin{array}{l}\text { One health, One world-The intersecting legal regimes of } \\
\text { trade, climate change, food security, humanitarian crises, } \\
\text { and migration }\end{array}$ \\
\hline 9 & Urdal and Che [12] & Henrik Urdal and Chi Primus Che & 2013 & $\begin{array}{l}\text { War and gender inequalities in health: The impact of } \\
\text { armed conflict on fertility and maternal mortality }\end{array}$ \\
\hline 10 & Turner, Turner, et al. [26] & $\begin{array}{l}\text { Claudia Turner, Paul Turner, Verena Carrara, Kathy } \\
\text { Burgoine, Saw Tha Ler Htoo, Wanitda Watthanaworawit, } \\
\text { Nicholas P. Day, Nicholas J. White, David Goldblatt, and } \\
\text { François Nosten }\end{array}$ & 2013 & $\begin{array}{l}\text { High aates of pneumonia in children under two years of } \\
\text { age in a south east Asian refugee population }\end{array}$ \\
\hline 11 & Turner, Carrara, et al. [25] & $\begin{array}{l}\text { Claudia Turner, Verena Carrara, Naw Aye Mya Thein, } \\
\text { Naw Chit Mo Mo Win, Paul Turner, Germana Bancone, } \\
\text { Nicholas J. White, Rose McGready, and François Nosten }\end{array}$ & 2013 & $\begin{array}{l}\text { Neonatal intensive care in a Karen refugee camp: } \\
\text { A four year descriptive study }\end{array}$ \\
\hline 12 & Parr et al. [27] & $\begin{array}{l}\text { Megan Parr, Colley Paw Dabu, Nan San Wai, Paw Si Say, } \\
\text { Ma Ner, Nay Win Tun, Aye Min, Mary Ellen Gilder, } \\
\text { François H Nosten, and Rose McGready }\end{array}$ & 2014 & \multirow{2}{*}{$\begin{array}{c}\text { Clinical audit to enhance safe practice of skilled birth } \\
\text { attendants for the fetus with nuchal cord: Evidence from } \\
\text { a refugee and migrant cohort } \\
\text { Understanding the Effects of mental health on } \\
\text { reproductive health service use: A mixed methods } \\
\text { approach }\end{array}$} \\
\hline 13 & Bell et al. [65] & $\begin{array}{l}\text { Sue Anne Bell, Jody Lori, Richard Redman, and Julia } \\
\text { Seng }\end{array}$ & 2015 & \\
\hline
\end{tabular}


Table A1. Cont.

\begin{tabular}{|c|c|c|c|c|}
\hline No & Author(s) [Citation No.] & Names of Author(s) & Year & Title of the Article \\
\hline 14 & White et al. [28] & $\begin{array}{c}\text { Adrienne Lynne White, Thaw Htwe Min, Mechthild M } \\
\text { Gross, Ladda Kajeechiwa, May Myo Thwin, Borimas } \\
\text { Hanboonkunupakarn, Hla Hla Than, Thet Wai Zin, } \\
\text { Marcus J Rijken, Gabie Hoogenboom, and Rose } \\
\text { McGready }\end{array}$ & 2016 & $\begin{array}{l}\text { Accelerated training of skilled birth attendants in a } \\
\text { marginalized population on the Thai-Myanmar border: } \\
\text { A multiple methods program evaluation }\end{array}$ \\
\hline 15 & Chelwa, Likwa and Banda [66] & $\begin{array}{c}\text { Nachela Malisenti Chelwa, Rosemary Ndonyo Likwa, } \\
\text { and Jeremiah Banda }\end{array}$ & 2016 & $\begin{array}{l}\text { Under-five mortality among displaced populations in } \\
\text { Meheba refugee camp, Zambia, 2008-2014 }\end{array}$ \\
\hline 16 & Khatoon et al. [67] & $\begin{array}{c}\text { Salina Khatoon, Shyam Sundar Budhathoki, Kiran Bam, } \\
\text { Rajshree Thapa, Lokesh P. Bhatt, Bidhya Basnet, and } \\
\text { Nilambar Jha }\end{array}$ & 2018 & $\begin{array}{c}\text { Socio-demographic characteristics and the utilization of } \\
\text { HIV testing and counselling services among the key } \\
\text { populations at the Bhutanese refugees camps in eastern } \\
\text { Nepal }\end{array}$ \\
\hline 17 & Parker et al. [24] & $\begin{array}{c}\text { Amber L. Parker, Daniel M. Parker, Blooming Night Zan, } \\
\text { Aung Myat Min, Mary Ellen Gilder, Maxime Ringringulu, } \\
\text { Elsi Win, Jacher Wiladphaingern, Prakaykaew } \\
\text { Charunwatthana, François Nosten, Sue J. Lee, and Rose } \\
\text { McGready }\end{array}$ & 2018 & $\begin{array}{c}\text { Trends and birth outcomes in adolescent refugees and } \\
\text { migrants on the Thailand-Myanmar border, 1986-2016: } \\
\text { An observational study }\end{array}$ \\
\hline 18 & Paromita et al. [68] & $\begin{array}{c}\text { Progga Paromita, Cinderella Akbar Mayaboti, Md. Abdul } \\
\text { Halim, and Animesh Biswas }\end{array}$ & 2019 & $\begin{array}{l}\text { Reproductive age mortality study (RAMOS) for } \\
\text { capturing underreporting maternal mortality: Why is } \\
\text { important in the Rohingya refugee camps, Bangladesh? }\end{array}$ \\
\hline 19 & Saleeb [13] & Christine Saleeb & 2020 & $\begin{array}{l}\text { Challenges and recommendations to reducing burden of } \\
\text { diphtheria in refugee camps }\end{array}$ \\
\hline 20 & Mwenyango [69] & Hadijah Mwenyango & 2020 & $\begin{array}{l}\text { The place of social work in improving access to health } \\
\text { services among refugees: A case study of Nakivale } \\
\text { settlement, Uganda }\end{array}$ \\
\hline 21 & Ganle et al. [70] & $\begin{array}{c}\text { John Kuumuori Ganle, Doris Amoako, Leonard Baatiema, } \\
\text { and Muslim Ibrahim }\end{array}$ & 2019 & $\begin{array}{l}\text { Risky sexual behaviour and contraceptive use in contexts } \\
\text { of displacement: Insights from a cross-sectional survey of } \\
\text { female adolescent refugees in Ghana }\end{array}$ \\
\hline 22 & Salisbury et al. [10] & $\begin{array}{c}\text { Patricia Salisbury, Layla Hall, Sibylla Kulkus, Moo Kho } \\
\text { Paw, Nay Win Tun, Aung Myat Min, Kesinee } \\
\text { Chotivanich, Somjet Srikanok, Pranee Ontuwong, } \\
\text { Supachai Sirinonthachai, François Nosten, Shawn } \\
\text { Somerset, and Rose McGready }\end{array}$ & 2016 & $\begin{array}{c}\text { Family planning knowledge, attitudes and practices in } \\
\text { refugee and migrant pregnant and post-partum women } \\
\text { on the Thailand-Myanmar border-a mixed methods } \\
\text { study }\end{array}$ \\
\hline 23 & Asnong et al. [23] & $\begin{array}{c}\text { Carine Asnong, Gracia Fellmeth, Emma Plugge, Nan San } \\
\text { Wai, Mupawjay Pimanpanarak, Moo Kho Paw, } \\
\text { Prakaykaew Charunwatthana, François Nosten, and Rose } \\
\text { McGready }\end{array}$ & 2018 & $\begin{array}{l}\text { Adolescents' perceptions and experiences of pregnancy } \\
\text { in refugee and migrant communities on the } \\
\text { Thailand-Myanmar border: A qualitative study }\end{array}$ \\
\hline 24 & Fellmeth et al. [22] & $\begin{array}{c}\text { Gracia Fellmeth, Emma Plugge, Moo Kho Paw, } \\
\text { Prakaykaew Charunwatthana, François Nosten, and Rose } \\
\text { McGready }\end{array}$ & 2015 & $\begin{array}{c}\text { Pregnant migrant and refugee women'sperceptions of } \\
\text { mental illness on the Thai-Myanmar border: } \\
\text { A qualitative study }\end{array}$ \\
\hline 25 & Adorjan et al. [6] & $\begin{array}{l}\text { K. Adorjan, S. Mulugeta, M. Odenwald, DM Ndetei, AH } \\
\text { Osman, M. Hautzinger, S. Wolf, M. Othman, JI Kizilhan, } \\
\text { O. Pogarell, and TG Schulze }\end{array}$ & 2017 & $\begin{array}{l}\text { Psychiatrische versorgung von flüchtlingen in Afrika und } \\
\text { dem Nahen Osten (translation: Psychiatric care for } \\
\text { refugees in Africa and the Middle East) }\end{array}$ \\
\hline 26 & Bellos et al. [11] & $\begin{array}{l}\text { Anna Bellos, Kim Mulholland, Katherine L O'Brien, } \\
\text { Shamim A Qazi, Michelle Gayer, and Francesco Checchi }\end{array}$ & 2010 & $\begin{array}{l}\text { The burden of acute respiratory infections in } \\
\text { crisis-affected populations: A systematic review }\end{array}$ \\
\hline 27 & (Bierhoff et al. [21] & $\begin{array}{l}\text { M. Bierhoff, M. J. Rijken, W. Yotyingaphiram, M. } \\
\text { Pimanpanarak, M. van Vugt, C. Angkurawaranon, F. } \\
\text { Nosten, S. Ehrhardt, C. L. Thio, and R. McGready }\end{array}$ & 2020 & $\begin{array}{c}\text { Tenofovir for prevention of mother to child transmission } \\
\text { of hepatitis B in migrant women in a resource-limited } \\
\text { setting on the Thailand-Myanmar border: A commentary } \\
\text { on challenges of implementation }\end{array}$ \\
\hline 28 & Schaaf et al. [71] & $\begin{array}{l}\text { Marta Schaaf, Victoria Boydell, Mallory C. Sheff1, } \\
\text { Christina Kay, Fatemeh Torabi, and Rajat Khosla }\end{array}$ & 2020 & $\begin{array}{c}\text { Accountability strategies for sexual and reproductive } \\
\text { health and reproductive rights in humanitarian settings: } \\
\text { A scoping review }\end{array}$ \\
\hline 29 & Balhara et al. [7] & $\begin{array}{l}\text { Kamna S. Balhara, David M. Silvestri, W. Tyler Winders, } \\
\text { Anand Selvam, Sean M. Kivlehan, Torben K. Becker, and } \\
\text { Adam C. Levine, Global Emergency Medicine Literature } \\
\text { Review Group (GEMLR) }\end{array}$ & 2017 & $\begin{array}{l}\text { Impact of nutrition interventions on pediatric mortality } \\
\text { and nutrition outcomes in humanitarian emergencies: A } \\
\text { systematic review }\end{array}$ \\
\hline 30 & Khan and DeYoung [14] & Aishah Khan and Sarah E. DeYoung & 2018 & $\begin{array}{l}\text { Maternal health services for refugee populations: } \\
\text { Exploration of best practices }\end{array}$ \\
\hline 31 & Meyer et al. [38] & $\begin{array}{l}\text { Sarah R Meyer, Gary Yu, Sabrina Hermosilla, and } \\
\text { Lindsay Stark }\end{array}$ & 2018 & $\begin{array}{c}\text { School violence, perceptions of safety and school } \\
\text { attendance: Results from a cross-sectional study in } \\
\text { Rwanda and Uganda }\end{array}$ \\
\hline 32 & Osman and Bin Ahmad Dahlan [46] & $\begin{array}{c}\text { Gamal Mohamed Osman and Abdul Rahman Bin Ahmad } \\
\text { Dahlan }\end{array}$ & 2019 & $\begin{array}{l}\text { Empowering Eritrean refugees in Sudan through quality } \\
\text { education for sustainable development }\end{array}$ \\
\hline 33 & Katsigianni and Kaila [39] & Victoria Katsigianni and Maria Kaila & 2019 & $\begin{array}{l}\text { Refugee education in Greece: A case study in primary } \\
\text { school }\end{array}$ \\
\hline 34 & Laxton et al. [35] & $\begin{array}{c}\text { Debra Laxton, Linda Cooper, Purna Shrestha, and Sarah } \\
\text { Younie }\end{array}$ & 2020 & $\begin{array}{l}\text { Translational research to support early childhood } \\
\text { education in crisis settings: A case study of collaborative } \\
\text { working with Rohingya refugees in Cox's Bazar }\end{array}$ \\
\hline 35 & Plessia [42] & Vasiliki Plessia & 2020 & $\begin{array}{l}\text { "Fallen angels" under European Union's migration } \\
\text { gesture }\end{array}$ \\
\hline 36 & Yeo, Gagnon and Thako [43] & Subin Sarah Yeo, Terese Gagnon, and Hayso Thako & 2020 & $\begin{array}{l}\text { Schooling for a atateless nation: The predicament of } \\
\text { education without consensus for karen refugees on the } \\
\text { Thailand-Myanmar border }\end{array}$ \\
\hline 37 & Gallagher and Bauer [45] & Matthew Gallagher and Carrie Bauer & 2020 & $\begin{array}{l}\text { Refugee higher education and future reconstruction } \\
\text { efforts: exploring the connection through the innovative } \\
\text { technological implementation of a university course in } \\
\text { Nakivale refugee settlement, Uganda }\end{array}$ \\
\hline 38 & Santo and Scott [36] & A Di Santo and KJ Scott & 2020 & $\begin{array}{l}\text { A child's right to early childhood education in emergency } \\
\text { contexts }\end{array}$ \\
\hline 39 & Piper et al. [41] & $\begin{array}{l}\text { Benjamin Piper, Sarah Dryden-Peterson, Vidur Chopra, } \\
\text { Celia Reddick, and Arbogast Oyanga } \\
\text { Elizabeth Walton, Joanna McIntyre, Salome Joy Awidi, }\end{array}$ & 2020 & $\begin{array}{l}\text { Are refugee children learning? early grade literacy in a } \\
\text { refugee camp in Kenya }\end{array}$ \\
\hline 40 & Walton et al. [32] & $\begin{array}{l}\text { Nicole De Wet-Billings, Kerryn Dixon, Roda Madziva, } \\
\text { David Monk, Chamunogwa Nyoni, Juliet Thondhlana, } \\
\text { and Volker Wedekind }\end{array}$ & 2020 & $\begin{array}{l}\text { Compounded exclusion: Education for disabled refugees } \\
\text { in Sub-Saharan Africa }\end{array}$ \\
\hline
\end{tabular}


Table A1. Cont.

\begin{tabular}{|c|c|c|c|c|}
\hline No & Author(s) [Citation No.] & Names of Author(s) & Year & Title of the Article \\
\hline 41 & O'keeffe [44] & O'keeffe, P. & 2020 & $\begin{array}{l}\text { The case for engaging online tutors for supporting } \\
\text { learners in higher education in refugee contexts }\end{array}$ \\
\hline 42 & Akua-Sakyiwah [40] & Beatrice Akua-Sakyiwah & 2020 & $\begin{array}{l}\text { Intersecting social structures and humanactors: Ganfoso } \\
\text { refugees' settling experiences and impact on children's } \\
\text { education }\end{array}$ \\
\hline 43 & Irfan [37] & Anne Irfan & 2016 & $\begin{array}{c}\text { The loss of education: Palestinian refugees from Syria } \\
\text { and UN SDG4 }\end{array}$ \\
\hline 44 & Jabbar and Zaza [47] & Sinaria Abdel Jabbara and Haidar Ibrahim Zazab & 2016 & $\begin{array}{l}\text { Evaluating a vocational training programme for women } \\
\text { refugees at the Zaatari camp in Jordan: women } \\
\text { empowerment: a journey and not an output }\end{array}$ \\
\hline 45 & Obodoruku [34] & Benedicta Obodoruku & 2019 & Syrian refugees and paucity of information \\
\hline 46 & Fatoni and Stewart [50] & Zainal Fatoni, and Donald E. Stewart & 2012 & $\begin{array}{l}\text { Sanitation in an emergency situation: A case study of the } \\
\text { eruption of Mt Merapi, Indonesia, } 2010\end{array}$ \\
\hline 47 & Faure, Faustand and Kaminsky [48] & Julie C. Faure, Kasey M. Faustand, and Jessica Kaminsky & 2019 & $\begin{array}{c}\text { Legitimization of the inclusion of cultural practicesin the } \\
\text { planning of water and sanitation services for displaced } \\
\text { persons }\end{array}$ \\
\hline 48 & Ajibade and Tota-Maharaj [16] & Oluwatoyin Opeyemi Ajibade, and Kiran Tota-Maharaj & 2018 & $\begin{array}{l}\text { Comparative study of sustainable drainage systems for } \\
\text { refugee camps stormwater management }\end{array}$ \\
\hline 49 & Abebe et al. [49] & $\begin{array}{l}\text { Lydia Abebe, Andrew J. Karon, Andrew J. Koltun, Ryan } \\
\text { D. Cronk, Robert E. S. Bain, and Jamie Bartram }\end{array}$ & 2018 & $\begin{array}{l}\text { Microbial contamination of non-household drinking } \\
\text { water sources: a systematic review }\end{array}$ \\
\hline 50 & Khoday and Gitonga [51] & Kishan Khoday and Stephen Gitonga & 2015 & Solar aid \\
\hline 51 & Lehne et al. [52] & $\begin{array}{c}\text { Johanna Lehne, William Blyth, Glada Lahn, Morgan } \\
\text { Bazilian, and Owen Grafham }\end{array}$ & 2016 & Energy services for refugees and displaced people \\
\hline 52 & Caniato, Carliez and Thulstrup [53] & $\begin{array}{c}\text { Marco Caniatoa, Daphné Carliezb, and Andreas } \\
\text { Thulstrup }\end{array}$ & 2017 & $\begin{array}{c}\text { Challenges and opportunities of new energy schemes for } \\
\text { food security in humanitarian contexts: A selective } \\
\text { review }\end{array}$ \\
\hline 53 & Benka-Coker et al. [54] & $\begin{array}{l}\text { Megan L. Benka-Cokera, Wubshet Tadeleb, Alex Milanoc, } \\
\text { Desalegn Getanehb, and Harry Stokes }\end{array}$ & 2018 & $\begin{array}{c}\text { A case study of the ethanol clean cook stove intervention } \\
\text { and potentialscale-up in Ethiopia } \\
\text { Trees, tensions, and transactional communities: }\end{array}$ \\
\hline 54 & Miller and Ulfstjerne [55] & Rachel L. Miller and Michael A. Ulfstjerne & 2020 & $\begin{array}{l}\text { Problematizing frameworksfor energy poverty } \\
\text { alleviation in the Rhino camp refugee settlement, Uganda }\end{array}$ \\
\hline 55 & Pearl-Martinez [56] & Rebecca Pearl-Martinez & 2020 & $\begin{array}{l}\text { Global trends impacting gender equality in energy access } \\
\text { International forced migration and Pak-Afghan }\end{array}$ \\
\hline 56 & Muhammad [58] & Rehan Khan Muhammad & 2011 & $\begin{array}{l}\text { development concerns: exploring Afghan refugee } \\
\text { livelihood trategies }\end{array}$ \\
\hline 57 & Schön et al. [33] & $\begin{array}{c}\text { Anna Schön, Shahad Al-Saadi, Jakob Grubmüller, and } \\
\text { Dorit Schumann-Bölsche }\end{array}$ & 2018 & $\begin{array}{c}\text { Developing a camp performance indicator system and its } \\
\text { application to Zaatari, Jordan }\end{array}$ \\
\hline 58 & Naoum [57] & Diana Naoum & 2016 & $\begin{array}{l}\text { Poverty and unemployment: Palestinian refugees in } \\
\text { Lebanon and the sustainable development goals } 1 \text { and } 8\end{array}$ \\
\hline 59 & Hayes [59] & Ben Hayes & 2017 & $\begin{array}{l}\text { Migration and data protection: Doing no harm in an age } \\
\text { of mass displacement mass surveillance and "big data" }\end{array}$ \\
\hline 60 & Brinham [60] & Natalie Brinham & 2019 & $\begin{array}{l}\text { Looking beyond invisibility: Rohingyas' dangerous } \\
\text { encounters with papers and cards }\end{array}$ \\
\hline 61 & Moreno-Serna et al. [62] & $\begin{array}{c}\text { Jaime Moreno-Serna, Teresa Sánchez-Chaparro, Javier } \\
\text { Mazorra, Ander Arzamendi, Leda Stott, and Carlos } \\
\text { Mataix }\end{array}$ & 2020 & $\begin{array}{l}\text { Transformational collaboration for the SDGs: The alianza } \\
\text { shire's work to provide energy access in refugee camps } \\
\text { and host communities }\end{array}$ \\
\hline 62 & Cheesman [61] & Margie Cheesman & 2020 & $\begin{array}{c}\text { Self-sovereignty for refugees? The contested horizons of } \\
\text { digital identity }\end{array}$ \\
\hline 63 & Nasser, Maclachlan and McVeigh [72] & $\begin{array}{l}\text { Khaled Nasser, Malcolm MacLachlan, and Joanne } \\
\text { McVeigh }\end{array}$ & 2016 & $\begin{array}{l}\text { Social inclusion and mental health of children with } \\
\text { physical disabilities in Gaza, Palestine }\end{array}$ \\
\hline 64 & Thielemans et al. [9] & $\begin{array}{c}\text { L. Thielemans, M. Trip-Hoving, J.Landier, C.Turner, } \\
\text { T.J.Prins, E.M.N.Wouda, B.Hanboonkunupakarn, C. Po, } \\
\text { C.Beau, M.Mu, T.Hannay, F. Nosten, B. Van Overmeire, R. } \\
\text { McGready, and V. I. Carrara }\end{array}$ & 2018 & $\begin{array}{l}\text { Indirect neonatal hyperbilirubinemia inhospitalized } \\
\text { neonates on the Thai-Myanmar border: A review of } \\
\text { neonatalmedical records from } 2009 \text { to } 2014\end{array}$ \\
\hline 65 & Mastor et al. [73] & $\begin{array}{l}\text { Roxana A. Mastor, Michael H. Dworkin, Mackenzie L. } \\
\text { Landa, and Emily Duff }\end{array}$ & 2018 & Energy justice and climate-refugees \\
\hline 66 & Shackelford et al. [74] & $\begin{array}{c}\text { Brandie Banner Shackelford, Ryan Cronk, Nikki Behnke, } \\
\text { Brittany Cooper, Raymond Tu, Mabel D'Souzaa, Jamie } \\
\text { Bartram, Ryan Schweitzer, and Dilshad Jaff }\end{array}$ & 2020 & $\begin{array}{l}\text { Environmental health in forced displacement: A } \\
\text { systematic scoping review of the emergency phase }\end{array}$ \\
\hline 67 & Nielsen [75] & Nielsen, B.F. & 2014 & $\begin{array}{l}\text { Imperatives and trade-offs for the humanitarian designer: } \\
\text { Off-grid energy for humanitarian relief }\end{array}$ \\
\hline 68 & Fetters et al. [76] & $\begin{array}{c}\text { Tamara Fetters, Sayed Rubayet, Sharmin Sultana, } \\
\text { Shamila Nahar, Shadie Tofigh, Lea Jones, Ghazaleh } \\
\text { Samandari, and Bill Powell } \\
\text { Samira Sami, Kate Kerber, Solomon Kenyi, Ribka Amsalu, }\end{array}$ & 2020 & $\begin{array}{c}\text { Navigating the crisis landscape: engagingthe ministry of } \\
\text { health and United Nations agencies to make abortion } \\
\text { care available to Rohingya refugees }\end{array}$ \\
\hline 69 & Sami et al. [77] & $\begin{array}{l}\text { Barbara Tomczyk, Debra Jackson, Alexander Dimiti, } \\
\text { Elaine Scudder, Janet Meyers, Jean Paul De Charles } \\
\text { Umurungi, Kemish Kenneth, and Luke C Mullany }\end{array}$ & 2017 & $\begin{array}{l}\text { State of newborn care in South Sudan's displacement } \\
\text { camps: A descriptive study of facility-based deliveries }\end{array}$ \\
\hline 70 & Sami et al. [78] & $\begin{array}{l}\text { Samira Sami, Ribka Amsalu, Alexander Dimiti, Debra } \\
\text { Jackson, Solomon Kenyi, Janet Meyers, Luke C. Mullany, } \\
\text { Elaine Scudder, Barbara Tomczyk, and Kate Kerber }\end{array}$ & 2018 & $\begin{array}{l}\text { Understanding health systems to improve community } \\
\text { and facility level newborn care among displaced } \\
\text { populations in South Sudan: a mixed methods case study }\end{array}$ \\
\hline 71 & $\begin{array}{l}\text { Khanfar, Al-Faqheri and Al-Halhouli } \\
\text { [79] }\end{array}$ & $\begin{array}{l}\text { Mohammad F. Khanfar, Wisam Al-Faqheri, and } \\
\text { Ala'aldeen Al-Halhouli }\end{array}$ & 2017 & $\begin{array}{l}\text { Low cost lab on chip for the colorimetric detection of } \\
\text { nitrate in mineral water products }\end{array}$ \\
\hline 72 & $\begin{array}{c}\text { Presler-Marshall, Jones and Odeh } \\
{[80]}\end{array}$ & $\begin{array}{c}\text { Elizabeth Presler-Marshall, Nicola Jones, and Kifah Bani } \\
\text { Odeh }\end{array}$ & 2020 & $\begin{array}{c}\text { "Even though I am blind, I am still human!": The neglect } \\
\text { of adolescents with disabilities' human rights in } \\
\text { conflict-affected contexts }\end{array}$ \\
\hline
\end{tabular}

\section{Appendix B}


Table A2. Included studies related to health and well-being.

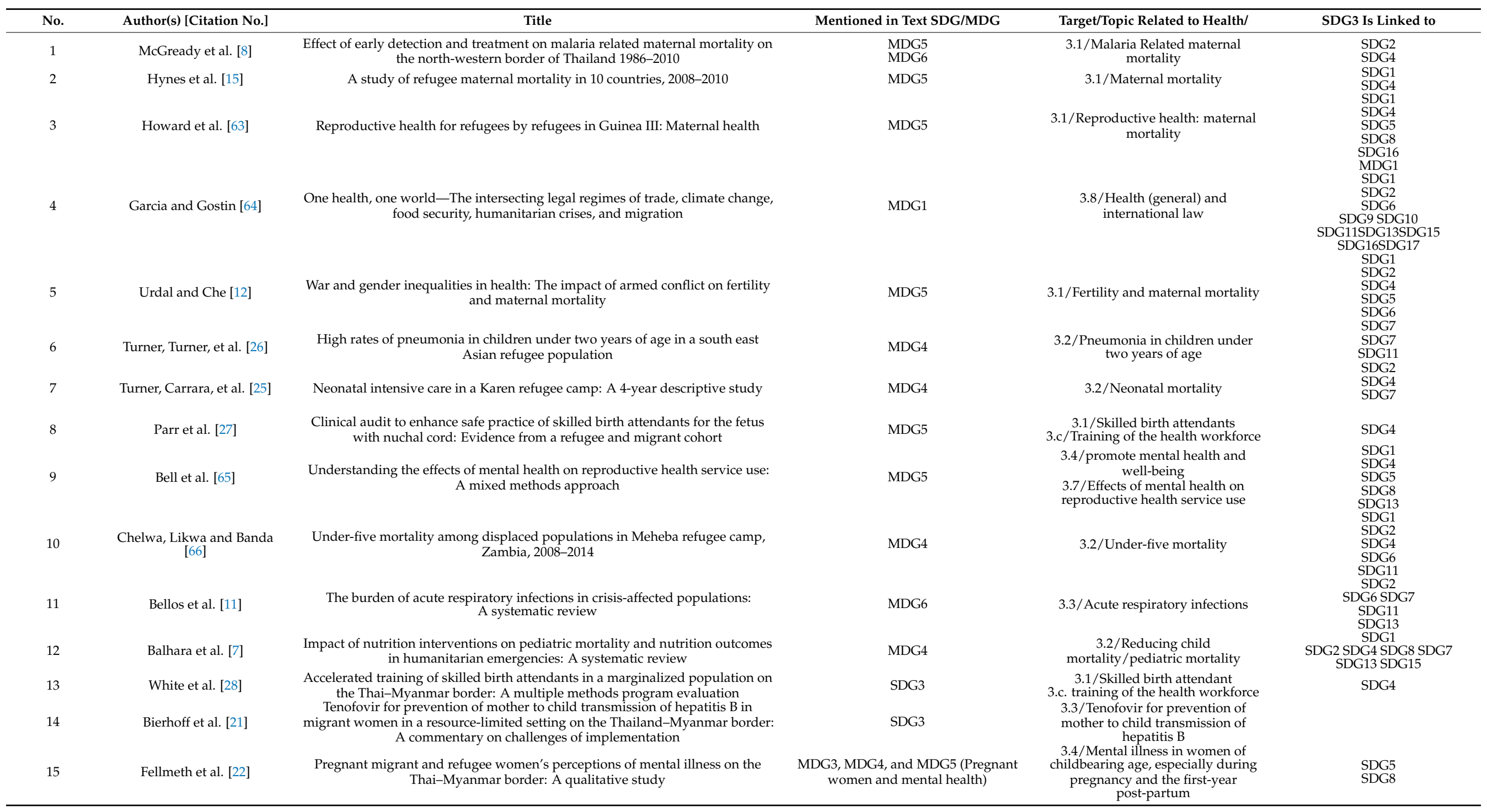


Table A2. Cont.

\begin{tabular}{|c|c|c|c|c|c|}
\hline No. & Author(s) [Citation No.] & Title & Mentioned in Text SDG/MDG & Target/Topic Related to Health/ & SDG3 Is Linked to \\
\hline 16 & Asnong et al. [23] & $\begin{array}{l}\text { Adolescents' perceptions and experiences of pregnancy in refugee and migrant } \\
\text { communities on the Thailand-Myanmar border: A qualitative study }\end{array}$ & SDG3 & 3.7/Adolescents' pregnancy & $\begin{array}{l}\text { SDG1, SDG2, SDG3, SDG4, } \\
\text { SDG5, SDG8, SDG10 }\end{array}$ \\
\hline 17 & Salisbury et al. [10] & $\begin{array}{l}\text { Family planning knowledge, attitudes and practices in refugee and migrant } \\
\text { pregnant and post-partum women on the Thailand-Myanmar border-a mixed } \\
\text { methods study }\end{array}$ & SDG3 & 3.7/Family planning & $\begin{array}{l}\text { SDG1 } \\
\text { SDG4 } \\
\text { SDG8 }\end{array}$ \\
\hline 18 & Parker et al. [24] & $\begin{array}{l}\text { Trends and birth outcomes in adolescent refugees and migrants on the } \\
\text { Thailand-Myanmar border, 1986-2016: An observational study }\end{array}$ & SDG3 & $\begin{array}{l}\text { 3.7/Sexual and reproductive } \\
\text { healthcare }\end{array}$ & SDG4 \\
\hline 19 & Schaaf et al. [71] & $\begin{array}{l}\text { Accountability strategies for sexual and reproductive health and reproductive } \\
\text { rights in humanitarian settings: Ascoping review }\end{array}$ & SDG3, SDG5, and SDG16 & $\begin{array}{l}\text { 3.7/Accountability strategies for } \\
\text { sexual and reproductive health and } \\
\text { reproductive rights }\end{array}$ & $\begin{array}{l}\text { SDG5 } \\
\text { SDG16 } \\
\text { SDG17. }\end{array}$ \\
\hline 20 & Khatoon et al. [67] & $\begin{array}{l}\text { Socio-demographic characteristics and the utilization of HIV testing and } \\
\text { counselling services among the key populations at the Bhutanese refugees } \\
\text { camps in eastern Nepal }\end{array}$ & SDG3 & $\begin{array}{l}\text { 3.3/Utilization of HIV testing and } \\
\text { counselling services }\end{array}$ & SDG1, SDG4 \\
\hline 21 & Paromita et al. [68] & $\begin{array}{l}\text { Reproductive age mortality study (RAMOS) for capturing underreporting } \\
\text { maternal mortality: why is important in the Rohingya refugee camps, } \\
\text { Bangladesh? }\end{array}$ & $\begin{array}{l}\text { SDG5 + SDGs (but it is related to } \\
\text { SDG3) }\end{array}$ & 3.1/Maternal mortality & $\begin{array}{l}\text { SDG1 } \\
\text { SDG5 }\end{array}$ \\
\hline 22 & Saleeb [13] & $\begin{array}{l}\text { Challenges and recommendations to reducing burden of diphtheria in refugee } \\
\text { camps }\end{array}$ & SDG3 & 3.3/Diphtheria & $\begin{array}{l}\text { SDG4 } \\
\text { SDG17 }\end{array}$ \\
\hline 23 & Mwenyang [69] & $\begin{array}{l}\text { The place of social work in improving access to health services among refugees: } \\
\text { A case study of Nakivale settlement, Uganda }\end{array}$ & SDG3 & $\begin{array}{l}\text { 3.8/Social work in improving access } \\
\text { to health services }\end{array}$ & $\begin{array}{l}\text { SDG1 } \\
\text { SDG5 } \\
\text { SDG8 } \\
\text { SDG10 } \\
\text { SDG16 } \\
\text { SDG1 } \\
\text { SDG4 } \\
\text { SDG5 } \\
\text { SDG10 } \\
\text { SDG16 SGD17 }\end{array}$ \\
\hline 25 & Khan and DeYoung [14] & $\begin{array}{l}\text { Psychiatrische versorgung von flüchtlingen in Afrika und dem Nahen Osten } \\
\text { (translation:Psychiatric care for refugees in Africa and the Middle East) }\end{array}$ & SDG3 + SDG10 (as text) & 3.4/Mental health and well-being & $\begin{array}{l}\text { SDG1 } \\
\text { SDG4 } \\
\text { SDG5 } \\
\text { SDG17 } \\
\text { SDG2 } \\
\text { SDG4 } \\
\text { SDG7 } \\
\text { SDG8 } \\
\text { SDG10 } \\
\text { SDG17 }\end{array}$ \\
\hline
\end{tabular}




\section{References}

1. UNHCR. UNHCR Engagement with the Sustainable Development Goals-Updated Guidance Note. 2019. Available online: www.unhcr.org (accessed on 12 October 2020).

2. UNHCR. The Sustainable Development Goals and the Global Compact on Refugees. 2020. Available online: https://www.unhcr. org/5efcb5004.pdf (accessed on 12 May 2021).

3. UNHCR. Convention and Protocol Relating to the Status of Refugees. 2010. Available online: https://www.refworld.org/docid/ 3be01b964.html (accessed on 13 April 2021).

4. UNHCR. UNHCR Master Glossary of Terms. 2006. Available online: https:/ / www.refworld.org/docid/42ce7d444.html (accessed on 13 April 2021).

5. Shah, A.; Jones, M.P.; Holtmann, G.J. Basics of meta-analysis. Indian J. Gastroenterol. 2020, 39, 503-513. [CrossRef]

6. Adorjan, K.; Mulugeta, S.; Odenwald, M.; Ndetei, D.M.; Osman, A.H.; Hautzinger, M.; Wolf, S.; Othman, M.; Kizilhan, J.I.; Pogarell, O; et al. Psychiatric care of refugees in Africa and the Middle East: Challenges and solutions. Nervenarzt 2017, 88, 974-982. [CrossRef] [PubMed]

7. Balhara, K.S.; Silvestri, D.M.; Tyler Winders, W.; Selvam, A.; Kivlehan, S.M.; Becker, T.K.; Levine, A.C. Impact of nutrition interventions on pediatric mortality and nutrition outcomes in humanitarian emergencies: A systematic review. Trop. Med. Int. Health 2017, 22, 1464-1492. [CrossRef]

8. McGready, R.; Boel, M.; Rijken, M.J.; Ashley, E.A.; Cho, T.; Moo, O.; Paw, M.K.; Pimanpanarak, M.; Hkirijareon, L.; Carrara, V.I.; et al. Effect of early detection and treatment on malaria related maternal mortality on the north-western border of thailand 1986-2010. PLoS ONE 2012, 7, e40244. [CrossRef] [PubMed]

9. Thielemans, L.; Trip-Hoving, M.; Landier, J.; Turner, C.; Prins, T.J.; Wouda, E.M.N.; Hanboonkunupakarn, B.; Po, C.; Beau, C.; Mu, M.; et al. Indirect neonatal hyperbilirubinemia inhospitalized neonates on the Thai-Myanmar border-A review of neonatalmedical records from 2009 to 2014. BMC Pediatr. 2018, 18, 190. [CrossRef]

10. Salisbury, P.; Hall, L.; Kulkus, S.; Paw, M.K.; Tun, N.W.; Min, A.M.; Chotivanich, K.; Srikanok, S.; Ontuwong, P.; Sirinonthachai, S.; et al. Family planning knowledge, attitudes and practices in refugee and migrant pregnant and post-partum women on the Thailand-Myanmar border-A mixed methods study. Reprod. Health 2016, 13. [CrossRef] [PubMed]

11. Bellos, A.; Mulholland, K.; O’Brien, K.L.; Qazi, S.A.; Gayer, M.; Checchi, F. The burden of acute respiratory infections incrisisaffected populations- a systematic review. Confl. Health 2010, 4, 1-12. [CrossRef]

12. Urdal, H.; Che, C.P. War and Gender Inequalities in Health: The Impact of Armed Conflict on Fertility and Maternal Mortality. Int. Interact. 2013, 39, 489-510. [CrossRef]

13. Saleeb, C. Challenges and Recommendations to Reducing Burden of Diphtheria in Refugee Camps. Glob. Health Annu. Rev. 2020, 1, 18-21.

14. Khan, A.; DeYoung, S.E. Maternal health services for refugee populations: Exploration of best practices. Glob. Public Health 2019, 14, 362-374. [CrossRef]

15. Hynes, M.; Sakani, O.; Spiegel, P.; Cornier, N. A study of refugee maternal mortality in 10 countries, 2008-2010. Int. Perspect. Sex. Reprod. Health 2012, 38, 205-213. [CrossRef] [PubMed]

16. Ajibade, O.O.; Tota-Maharaj, K. Comparative study of sustainable drainage systems for refugee camps stormwater management. Proc. Inst. Civ. Eng. Munic. Eng. 2018, 171, 149-162. [CrossRef]

17. Earle, L. Urban crises and the new urban agenda. Environ. Urban. 2016, 28, 77-86. [CrossRef]

18. Jahre, M.; Kembro, J.; Adjahossou, A.; Altay, N. Approaches to the design of refugee camps: An empirical study in Kenya, Ethiopia, Greece, and Turkey. J. Humanit. Logist. Supply Chain Manag. 2018, 8, 323-345. [CrossRef]

19. Rush, D.; Bankoff, G.; Cooper-Knock, S.J.; Gibson, L.; Hirst, L.; Jordan, S.; Spinardi, G.; Twigg, J.; Walls, R.S. Fire risk reduction on the margins of an urbanizing world. Disaster Prev. Manag. Int. J. 2020, 29, 747-760. [CrossRef]

20. Youssef, M.; Mefleh, F. Towards a Creative Sustainable Promenade in Informal Souk Architecturecase Study: Mar Elias Camps, in Beirut, Lebanon. BAU J. Creat. 2019, 1, 1-15.

21. Bierhoff, M.; Rijken, M.J.; Yotyingaphiram, W.; Pimanpanarak, M.; Van Vugt, M.; Angkurawaranon, C.; Nosten, F.; Ehrhardt, S.; Thio, C.L.; McGready, R. Tenofovir for prevention of mother to child transmission of hepatitis B in migrant women in a resourcelimited setting on the Thailand-Myanmar border: A commentary on challenges of implementation. Int. J. Equity Health $2020,19$. [CrossRef]

22. Fellmeth, G.; Plugge, E.; Paw, K.M.; Charunwatthana, P.; Nosten, F.; McGready, R. Pregnant migrant and refugee women's perceptions of mental illness on the Thai-Myanmar border: A qualitative study. BMC Pregnancy Childbirth 2015, 15, 1-11. [CrossRef]

23. Asnong, C.; Fellmeth, G.; Plugge, E.; Wai, N.S.; Pimanpanarak, M.; Paw, M.K.; Charunwatthana, P.; Nosten, F.; McGready, R. Adolescents' perceptions and experiences of pregnancy in refugee and migrant communities on the Thailand-Myanmar border: A qualitative study. Reprod. Health 2018, 15, 1-13. [CrossRef]

24. Parker, A.L.; Parker, D.M.; Zan, B.N.; Min, A.M.; Gilder, M.E.; Ringringulu, M.; Win, E.; Wiladphaingern, J.; Charunwatthana, P.; Nosten, F.; et al. Trends and birth outcomes in adolescent refugees and migrants on the Thailand-Myanmar border, 1986-2016: An observational study [version 1; referees: 2 approved]. Wellcome Open Res. 2018, 3. [CrossRef]

25. Turner, C.; Carrara, V.; Thein, N.A.M.; Mo Mo Win, N.C.; Turner, P.; Bancone, G.; White, N.J.; McGready, R.; Nosten, F. Neonatal Intensive Care in a Karen Refugee Camp: A 4 Year Descriptive Study. PLoS ONE 2013, 8. [CrossRef] [PubMed] 
26. Turner, C.; Turner, P.; Carrara, V.; Burgoine, K.; Tha Ler Htoo, S.; Watthanaworawit, W.; Day, N.P.; White, N.J.; Goldblatt, D.; Nosten, F. High Rates of Pneumonia in Children under Two Years of Age in a South East Asian Refugee Population. PLoS ONE 2013, 8. [CrossRef]

27. Parr, M.; Dabu, C.P.; Wai, N.S.; Say, P.S.; Ner, M.; Tun, N.W.; Min, A.; Gilder, M.E.; Nosten, F.H.; McGready, R. Clinical audit to enhance safe practice of skilled birth attendants for the fetus with nuchal cord: Evidence from a refugee and migrant cohort. BMC Pregnancy Childbirth 2014, 14. [CrossRef] [PubMed]

28. White, A.L.; Min, T.H.; Gross, M.M.; Kajeechiwa, L.; Thwin, M.M.; Hanboonkunupakarn, B.; Than, H.H.; Zin, T.W.; Rijken, M.J.; Hoogenboom, G.; et al. Accelerated Training of Skilled Birth Attendants in a Marginalized Population on theThai-Myanmar Border: A Multiple Methods Program Evaluation. PLoS ONE 2016, 11, e0164363. [CrossRef]

29. UN. Global Indicator Framework for the Sustainable Development Goals and Targets of the 2030 Agenda for Sustainable Development Goals and Targets (from the 2030 Agenda for Sustainable Development) Indicators. 2020. Available online: https://unstats.un.org/sdgs/indicators/GlobalIndicatorFrameworkafter2020review_Eng.pdf (accessed on 13 March 2021).

30. UNHCR. Refugee Education 2030: A Strategy for Refugee Inclusion. 2019. Available online: https://data2.unhcr.org/en/ documents/download/71213 (accessed on 12 March 2021).

31. UNHCR. Refugee Education in Crisis: More than Half of the World's School-Age Refugee Children Do Not Get an Education. 2019. Available online: https:/ / www.unhcr.org/news/press/2019/8/5d67b2f47/refugee-education-crisis-half-worlds-schoolage-refugee-children-education.html (accessed on 1 March 2021).

32. Walton, E.; McIntyre, J.; Awidi, S.J.; De Wet-Billings, N.; Dixon, K.; Madziva, R.; Monk, D.; Nyoni, C.; Thondhlana, J.; Wedekind, V. Compounded Exclusion: Education for Disabled Refugees in Sub-Saharan Africa. Front. Educ. 2020, 5, 1-14. [CrossRef]

33. Schön, A.M.; Al-Saadi, S.; Grubmueller, J.; Schumann-Bölsche, D. Developing a camp performance indicator system and its application to Zaatari, Jordan. J. Humanit. Logist. Supply Chain Manag. 2018, 8, 346-373. [CrossRef]

34. Obodoruku, B. Syrian Refugees and Paucity of Information. Inf. Needs Refug. Sustain. Dev. Goals 2019, $23,1-31$.

35. Laxton, D.; Cooper, L.; Shrestha, P.; Younie, S. Translational research to support early childhood education in crisis settings: A case study of collaborative working with Rohingya refugees in Cox's Bazar. Education 2020. [CrossRef]

36. Di Santo, A.; Scott, K.-J. A Child's Right to Early Childhood Education in Emergency Contexts. Can. J. Child. Rights 2020, 7, 241-262. [CrossRef]

37. Irfan, A. The Loss of education: Palestinian refugees from Syria and UN SDG 4. J. Palest. Refug. Stud. 2016, 6, 21-26. [CrossRef]

38. Meyer, S.R.; Yu, G.; Hermosilla, S.; Stark, L. School violence, perceptions of safety and school attendance: Results from a cross-sectional study in Rwanda and Uganda. J. Glob. Health Rep. 2018, 2. [CrossRef]

39. Katsigianni, V.; Kaila, M. Refugee Education in Greece: A Case Study in Primary School. IJAEDU Int. E J. Adv. Educ. 2019, 5, 352-360. [CrossRef]

40. Akua-Sakyiwah, B. Intersecting social structures and humanactors- Ganfoso refugees'settlingexperiences and impact on children'seducation.pdf. Comp. Migr. Stud. 2020, 43, 1-17.

41. Piper, B.; Dryden-Peterson, S.; Chopra, V.; Reddick, C.; Oyanga, A. Are Refugee Children Learning? Early Grade Literacy in a Refugee Camp in Kenya. J. Educ. Emergencies 2020, 5, 71. [CrossRef]

42. Plessia, V. “Fallen Angels” under European Union's migration gesture. HAPSc Policy Briefs Ser. 2020, 1, 219. [CrossRef]

43. Yeo, S.S.; Gagnon, T.; Thako, H. Schooling for a stateless nation: The predicament of education without consensus for Karen refugees on the Thailand-Myanmar border. Asian J. Peacebuild. 2020, 8, 29-55. [CrossRef]

44. O'keeffe, P. The case for engaging online tutors for supporting learners in higher education in refugee contexts. Res. Learn. Technol. 2020, 28, 1-15. [CrossRef]

45. Gallagher, M.; Bauer, C. Refugee Higher Education and Future Reconstruction Efforts: Exploring the Connection through the Innovative Technological Implementation of a University Course in Nakivale Refugee Settlement, Uganda. Curr. Issues Comp. Educ. 2020, 22, 39-57.

46. Osman, G.M.; Bin Ahmad Dahlan, A.R. Empowering Eritrean refugees in Sudan through Quality Education for sustainable development. Int. J. Soc. Sci. Humanit. Res. 2019, 7, 476-483.

47. Jabbar, S.A.; Zaza, H.I. Evaluating a vocational training programme for women refugees at the Zaatari camp in Jordan: Women empowerment: A journey and not an output. Int. J. Adolesc. Youth 2016, 21, 304-319. [CrossRef]

48. Faure, J.C.; Faustand, K.M.; Kaminsky, J. Legitimization of the Inclusion of Cultural Practicesin the Planning of Water and Sanitation Services for Displaced Persons. Water 2019, 11, 359. [CrossRef]

49. Abebe, L.; Karon, A.J.; Koltun, A.J.; Cronk, R.D.; Bain, R.E.S.; Bartram, J. Microbial contamination of non-household drinking water sources: A systematic review. J. Water Sanit. Hyg. Dev. 2018, 8, 374-385. [CrossRef]

50. Fatoni, Z.; Stewart, D.E. Sanitation in An Emergency Situation: A Case Study of The Eruption of Mount Merapi, Indonesia, 2010. Int. J. Environ. Prot. 2012, 2, 1-5.

51. Khoday, K.; Gitonga, S. Solar aid. Oxf. Energy Forum 2015, 102, 52-55.

52. Lehne, J.; Blyth, W.; Lahn, G.; Bazilian, M.; Grafham, O. Energy services for refugees and displaced people. Energy Strateg. Rev. 2016, 13-14, 134-146. [CrossRef]

53. Caniato, M.; Carliez, D.; Thulstrup, A. Challenges and opportunities of new energy schemes for food security in humanitarian contexts: A selective review. Sustain. Energy Technol. Assess. 2017, 22, 208-219. [CrossRef] 
54. Benka-Coker, M.L.; Tadele, W.; Milano, A.; Getaneh, D.; Stokes, H. A case study of the ethanol CleanCook stove intervention and potential scale-up in Ethiopia. Energy Sustain. Dev. 2018, 46, 53-64. [CrossRef]

55. Miller, R.L.; Ulfstjerne, M.A. Trees, tensions, and transactional communities: Problematizing frameworks for energy poverty alleviation in the Rhino Camp refugee settlement, Uganda. Energy Res. Soc. Sci. 2020, 63. [CrossRef]

56. Pearl-Martinez, R. Global Trends Impacting Gender Equality in Energy Access. IDS Bull. 2020, 51, 7-26. [CrossRef]

57. Naoum, D. Poverty and Unemployment: Palestinian Refugees in Lebanon and the Sustainable Development Goals 1 and 8. J. Palest. Refug. Stud. 2016, 6, 27-31. [CrossRef]

58. Muhammad, R.K. International Forced Migration and Pak- Afghan Development Concerns: Exploring Afghan Refugee Livelihood Strategies. J. Soc. Dev. Sci. 2011, 2, 181-187. [CrossRef]

59. Hayes, B. Migration and data protection: Doing no harm in an age of mass displacement, mass surveillance and "big data". Int. Rev. Red Cross 2017, 99, 179-209. [CrossRef]

60. Brinham, N. Looking beyond invisibility: Rohingyas' dangerous encounters with papers and cards. Tilbg. Law Rev. 2019, 24, 156-169. [CrossRef]

61. Cheesman, M. Self-Sovereignty for Refugees-The Contested Horizons of Digital Identity.pdf. Geopolitics 2020, 1-27. [CrossRef]

62. Moreno-Serna, J.; Sánchez-Chaparro, T.; Mazorra, J.; Arzamendi, A.; Stott, L.; Mataix, C. Transformational collaboration for the SDGs: The alianza shire's work to provide energy access in refugee camps and host communities. Sustainability 2020, $12,539$. [CrossRef]

63. Howard, N.; Woodward, A.; Souare, Y.; Kollie, S.; Blankhart, D.; Von Roenne, A.; Borchert, M. Reproductive health for refugees by refugees in Guinea III- maternal health. Confl. Health 2011, 5, 1-8. [CrossRef]

64. Garcia, K.K.; Gostin, L.O. One Health, One World-The Intersecting Legal Regimes of Trade, Climate Change, Food Security, Humanitarian Crises, and Migration. Laws 2012, 1, 4-38. [CrossRef]

65. Bell, S.A.; Lori, J.; Redman, R.; Seng, J. Understanding the Effects of Mental Health on Reproductive Health Service Use: A Mixed Methods Approach. Health Care Women Int. 2016, 37, 75-96. [CrossRef]

66. Chelwa, N.M.; Likwa, R.N.; Banda, J. Under-five mortality among displaced populations in Meheba refugee camp, Zambia, 2008-2014. Arch. Public Health 2016, 74, 49. [CrossRef]

67. Khatoon, S.; Budhathoki, S.S.; Bam, K.; Thapa, R.; Bhatt, L.P.; Basnet, B.; Jha, N. Socio-demographic characteristics and the utilization of HIV testing and counselling services among the key populations at the Bhutanese Refugees Camps in Eastern Nepal. BMC Res. Notes 2018, 11, 1-6. [CrossRef]

68. Paromita, P.; Mayaboti, C.A.; Halim, A.M.; Biswas, A. Reproductive age mortality study (RAMOS) for capturing underreporting maternal mortality: Why is it important in the Rohingya refugee camps, Bangladesh? Int. J. Percept. Public Health 2019, 3, 55-65. [CrossRef]

69. Mwenyango, H. The place of social work in improving access to health services among refugees: A case study of Nakivale settlement, Uganda. Int. Soc. Work 2020, 1-15. [CrossRef]

70. Ganle, J.K.; Amoako, D.; Baatiema, L.; Ibrahim, M. Risky sexual behaviour and contraceptiveuse in contexts of displacementinsightsfrom a cross-sectional survey of femaleadolescent refugees in Ghana. Int. J. Equity Health 2019, 127, 1-11.

71. Schaaf, M.; Boydell, V.; Sheff, M.C.; Kay, C.; Torabi, F.; Khosla, R. Accountability strategies for sexual and reproductive health and reproductive rights in humanitarian settings: A scoping review. Confl. Health 2020, 14, 1-18. [CrossRef] [PubMed]

72. Nasser, K.; Maclachlan, M.; McVeigh, J. Social inclusion and mental health of children with physical disabilities in gaza, Palestine. Disabil. CBR Incl. Dev. 2016, 27, 5-36. [CrossRef]

73. Mastor, R.; Dworkin, M.; Landa, M.; Duff, E. Energy Justice and Climate-Refugees. Energy Law J. 2018, $39,139$.

74. Shackelford, B.B.; Cronk, R.; Behnke, N.; Cooper, B.; Tu, R.; D’Souzaa, M.; Bartram, J.; Schweitzer, R.; Jaff, D. Environmental health in forced displacement: A systematic scoping review of the emergency phase. Sci. Total Environ. 2020, 714, 136553. [CrossRef]

75. Nielsen, B.F. Imperatives and trade-offs for the humanitarian designer: Off-grid energy for humanitarian relief. J. Sustain. Dev. 2014, 7, 15-24. [CrossRef]

76. Fetters, T.; Rubayet, S.; Sultana, S.; Nahar, S.; Tofigh, S.; Jones, L.; Samandari, G.; Powell, B. Navigating the crisis landscape: Engaging the ministry of health and United Nations agencies to make abortion care available to Rohingya refugees. Confl. Health 2020, 14, 1-8. [CrossRef]

77. Sami, S.; Kerber, K.; Kenyi, S.; Amsalu, R.; Tomczyk, B.; Jackson, D.; Dimiti, A.; Scudder, E.; Meyers, J.; Umurungi, J.P.D.C.; et al. State of newborn care in South Sudan's displacement camps: A descriptive study of facility-based deliveries. Reprod. Health 2017, 14, 1-12. [CrossRef]

78. Sami, S.; Amsalu, R.; Dimiti, A.; Jackson, D.; Kenyi, S.; Meyers, J.; Mullany, L.C.; Scudder, E.; Tomczyk, B.; Kerber, K. Understanding health systems to improve community and facility level newborn care among displaced populations in South Sudan: A mixed methods case study. BMC Pregnancy Childbirth 2018, 18, 1-12. [CrossRef] [PubMed]

79. Khanfar, M.F.; Al-Faqheri, W.; Al-Halhouli, A. Low cost lab on chip for the colorimetric detection of nitrate in mineral water products. Sensors 2017, 17, 2345. [CrossRef] [PubMed]

80. Presler-Marshall, E.; Jones, N.; Odeh, K.B. 'Even though I Am Blind, I Am Still Human!': The Neglect of Adolescents with Disabilities' Human Rights in Conflict-Affected Contexts. Child Indic. Res. 2020, 13, 513-531. [CrossRef] 